\title{
Integrating Geoheritage into the Management of Protected Areas: Proposal for the Itatiaia National Park, Brazil
}

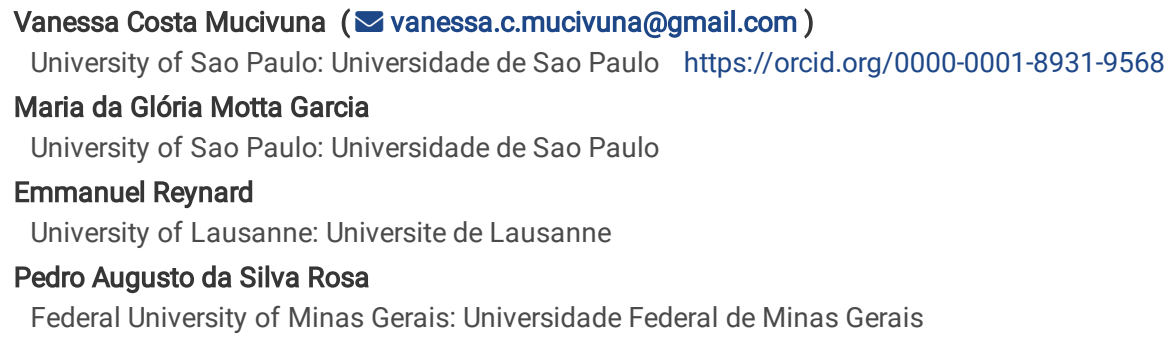

\section{Research Article}

Keywords: Assessment, Geoconservation, Geodiversity, Geoheritage, Inventory, Management Plan

Posted Date: September 16th, 2021

DOI: https://doi.org/10.21203/rs.3.rs-862530/v1

License: () (1) This work is licensed under a Creative Commons Attribution 4.0 International License. Read Full License

Version of Record: A version of this preprint was published at International Journal of Geoheritage and Parks on June 1st, 2022. See the published version at https://doi.org/10.1016/j.ijgeop.2022.04.004. 


\section{Abstract}

The International Union for Conservation of Nature (IUCN) has created many initiatives to integrate geodiversity and geoheritage into the management of protected areas through a broader concept of nature. Many protected areas, however, do not have an inventory of geoheritage sites. In view of this fact, this study aims to discuss the geoheritage inventory and to analyse, through a case study, how geodiversity is described in an existing management plan, prepared before IUCN included geoheritage in the Manual for the Management of Protected Areas. This study was conducted in the Itatiaia National Park, which has outstanding geological and geomorphological features. To ensure appropriate assessment of geological sites (including geomorphological, hydrological, petrological, sedimentary, structural sites, etc.), we took inventory of geoheritage and then analysed how the management plan addresses geodiversity. The geoheritage inventory includes 17 geosites distributed in six geological frameworks, seven geodiversity sites and three viewpoints. We concluded that although geodiversity is mentioned in the plan, the geoheritage inventory would facilitate and support the exploration of management possibilities that range from protection to education. Therefore, we recommend the inclusion of geoheritage inventory in the management plans of protected areas because it is a valuable tool for the proper conservation and management of geoheritage.

\section{Introduction}

Since the International Conference on the Protection of Geological Heritage in 1991 (Martini 1994) and the Malvern Conference in 1993 (O'Halloran et al. 1994), initiatives and research focused on geodiversity and geoheritage have increased around the world (Reynard and Brilha 2018). In this context, geoconservation has emerged to prevent sites of geoscientific importance from being destroyed (Sharples 2002; Gray 2004, 2013; Henriques et al. 2011; Prosser 2013). After nearly 30 years of initial discussions, however, geodiversity does not cause the same level of concern that is expressed about biodiversity. For example, neither the Earth Summit in Rio de Janeiro (1992) nor the Millennium Declaration (2000) and the United Nations Sustainable Development Goals (SDGs) (2015) have included geoheritage as a central issue. Although geoconservation is not on the United Nations' main political agenda, geodiversity and geoheritage have recently been included on the agendas of the International Union for Conservation of Nature (IUCN) and United Nations, Scientific and Cultural Organisation (UNESCO) (Crofts and Gordon 2015; Brilha 2018; Crofts 2018; Reynard and Brilha 2018; Crofts et al. 2020).

The fact that geodiversity and geoheritage are not mentioned in official documents is not a result of lack of research on such topics. Brilha (2017) points out that the number of papers, dissertations, theses and scientific conferences is growing worldwide; however, most countries still do not have their geoheritage protected and/or included in nature conservation policies (Reynard and Brilha 2018). On the other hand, some countries have developed geoconservation policies and measures to protect their geodiversity and geoheritage, such as the Great Britain (England, Scotland and Wales) (National Parks and Access to the Countryside Act - 1949), Spain (Law on Natural Heritage and Biodiversity - 2007) and Norway (Nature Diversity Act - 2009) (Gordon et al. 2018a).

One of the reasons that could explain why geodiversity and geoheritage are usually not officially protected is the widespread idea that geodiversity is resistant and durable (Gray 2013), unlike biodiversity, an assumption that has proved to be wrong. Geodiversity is actually a non-renewable resource, has finite extensions and can be affected by natural or human threats (Thomas,2012; Bétard and Peulvast 2019). Another possible explanation could be the fact that international conventions and agreements have addressed it short until very recently, which made it challenging to prioritise geodiversity and geoheritage in public policies, as there is a lack of statutory protection tools to be used by national nature conservation agencies and managers (Crofts et al. 2021).

Recently, there has been a growing effort to integrate geoconservation into environmental and management policies (Crofts and Gordon 2014, 2015; DíazMartínez et al. 2016, 2017; Crofts 2018; Brilha et al. 2018; Gordon et al. 2018a, 2018b; Crofts et al. 2020). The IUCN has put several issues related to geoconservation on its agenda, strongly influenced by new board members who represent institutions that are related to this theme. Geodiversity has been recognised as an integral part of nature and geoheritage as part of the natural heritage (Crofts and Gordon 2015). A Geoheritage Specialist Group has been created in the World Commission on Protected Areas (WCPA) (Woo 2017), a chapter on Geoconservation has been included in the Manual for the Management of Protected Areas published by IUCN (Crofts and Gordon 2015), and specific best practice guidelines on geoconservation in protected and conserved areas have been recently published (Crofts et al. 2020). Also, since 2008 almost 20 resolutions have been adopted by the IUCN (e.g. $4.040 / 2008$, 048/2012,091/2016,089/2020) to include geoconservation in the international legal framework (Díaz-Martínez et al.

2017, https://portals.iucn.org/library/resrec/search).

Several authors (e.g. Matthews 2014; Crofts and Gordon 2014, 2015; Brilha and Reynard 2018; Crofts 2018; Gordon et al. 2018a, 2018b) have emphasised the challenges faced by geoconservation in protected areas (PAs), highlighting that the integration of abiotic aspects into their management remains a crucial unresolved issue for nature conservation. For example, Brilha (2002) stated that in the $20^{\text {th }}$ century, geoconservation was not a priority for PAs managers, as many of them were not geoscientists nor had a good knowledge of abiotic aspects. Therefore, the geology and geomorphology of these areas have only been indirectly conserved due to biological, aesthetic and cultural values (Dingwall 2000).

In this context, the appropriate recognition of geoheritage in PAs is essential for its conservation and management. A systematic inventory, based on a reliable method of identification and assessment and solid criteria could guarantee a clear diagnosis of potentialities and threats and avoid the partial or total loss of records of the Earth's geological history.

Including inventoried sites in PAs management plans (MPs), either as a broader landscape element or their intrinsic features and scientific value (Dingwall 2000), could contribute to the appropriate management of abiotic aspects (Crofts et al. 2020), as well as promoting geodiversity, so that it causes the same level of concern that is currently shown about biodiversity (Crofts and Gordon 2015).

Considering the importance of geoconservation in PAs, the aims of this work are (i) to discuss the method and results of the inventory of geological sites (including geosites, geodiversity sites and viewpoints) in the Itatiaia National Park (INP), (ii) to analyse how geodiversity is addressed in the MP and (iii) to evaluate the possibilities of including the inventoried sites in the MP guidelines in order to ensure their effective management.

Page $2 / 21$ 


\section{Nature Conservation And The Role Of Protected Areas 2.1 The protection of nature in the global context}

At the turn of the $20^{\text {th }}$ century, the growth in agricultural and industrial activities was responsible for a change in nature conservation paradigm. At that time, nature conservation and management were focused on (i) landscape conservation by land-use policies and laws (Europe) and (ii) wilderness protection (USA) (Castro Júnior et al. 2009). The Yellowstone National Park in the US is considered the first PA established in 1872. Later, others were created in Canada (1885), New Zealand (1894), Australia, South Africa, Mexico (1898), Argentina (1903), Sweden (1909), Switzerland (1914), Chile (1926), Ecuador (1934), Brazil and Venezuela (1937) (Medeiros, 2003). This movement fostered the creation of IUCN in 1948, aiming at the conservation and sustainable use of nature. IUCN defines PA as "a clearly defined geographical space, recognised, dedicated and managed, through legal or other effective means, to achieve the long-term conservation of nature with associated ecosystem services and cultural values" and classifies them into: (la) Strict nature reserve and (Ib) Wilderness area, (II) National park, (III) Natural monument, (IV) Habitat/species management area, (V) Protected landscape/seascape, (VI) protected area with sustainable use of natural resources (Dudley 2008).

The growing concern for nature conservation has contributed to the creation of PAs around the world. The global network of PAs covers $14.7 \%$ of land area and $10 \%$ of territorial waters under protection (IUCN 2016).

\subsection{Brazilian protected areas}

The first mention of nature conservation in the Brazilian Constitution was in 1934. In that same year, the Forest Code (Decree No. 23,793/1934, amended by Law No. 4,771/1965 and No. 12,651/2012) established the rules for protecting Permanent Protect Areas (Medeiros, 2003), and three years later the INP was created.

After these initiatives and following global trends, several policies were developed to protect and maintain the environment's integrity. These include the rules for creating Ecological Stations and Environmental Protection Areas (Law No. 6,902/1981), Ecological Reserves and Area of Relevant Ecological Interest (Decree No. 89,336/1984) and Private Natural Heritage Reserves (Law No. 1,922/1996) (Medeiros et al. 2004; Medeiros 2006).

One of the most important laws is the National System of Protected Areas (NSPA) (Law No. 9,985/2000), which was adopted to guarantee PAs' creation, management, and consolidation (Brasil 2000). According to the NSPA, PAs are classified into strictly protected areas, in which only the indirect use of natural resources is allowed (ecological station, biological reserve, national park, natural monument, and wildlife refuge) and sustainable-use protected areas, in which the controlled exploitation of some natural resources is allowed (environmental protection area, area of relevant ecological interest, national forest, extractive reserve, fauna reserve, sustainable development reserve, and private natural heritage reserve).

These areas must prepare a MP within five years from the date of their creation in order to regulate and guide the general objectives, zoning, rules and restrictions of use (Brasil 2000). However, despite the importance of geological and geomorphological aspects for maintaining ecosystems, these elements are not satisfactorily elaborated in these documents (Garcia et al. 2019a), which hinders the integrated management of biodiversity and geodiversity, reducing the potential for geoheritage conservation and promotion.

Management plans were officially established in Brazil in 1979, aiming to guide national parks' management (Brasil 1979). The enactment of Law No. $9,985 / 2000$ reinforced it as a tool central to the management process for all categories of PAs (Brasil 2000). According to the NSPA, a MP is a technical document that, based on the general objectives of a PA, defines its zoning and the rules that should regulate the use and management of natural resources, including the installation of the physical structures required for its management (Brasil 2000). It must cover not only the core zone but also its buffer zone and wildlife corridors.

Among the goals of the MP, the following stand out: i) meeting the objectives established when the PA was created; ii) defining the management objectives, guiding its management, iii) describing the guidelines for its development, iv) defining the specific management actions, v) establishing the zoning for the protection of natural and cultural resources, vi) promoting the social and economic integration of the surrounding communities, and vii) guiding the use of the financial resources allocated to the PA (Galante et al. 2002).

There are different guidelines for the preparation of MPs according to the category of PAs. These guidelines must be followed in order to standardise these documents and guarantee systematic planning. Therefore, to integrate the different existing documents for preparing MPs, the ICMBio published new methodological guidelines for preparing and revising MPs at the federal level, aiming to standardise planning across their different categories (D'Amico et al. 2018).

\section{Study Area}

\subsection{General context}

Located in Mantiqueira Mountain Range, in the southeast of Brazil, the INP has almost $280 \mathrm{Km}^{2}$ with altitudes ranging between 540 and $2791 \mathrm{~m}$. (IBGE 2016 ). Its boundaries covers the municipalities of Itatiaia and Resende, in the state of Rio de Janeiro, and Bocaina de Minas and Itamonte, in the state of Minas Gerais (Fig. 1). 
The INP is part of the Atlantic Forest Biome, standing out as one of the 25 biodiversity hotspots in the world (Myers et al. 2000), and is recognised as a Biosphere Reserve by UNESCO since 1991 and as natural heritage by the Brazilian Constitution (Brasil 1988). It is also classified as a priority area for biodiversity conservation (MMA 2014), and its flora is classified into Vegetation Refuge, Dense High Ombrophilous Montane Forest, Dense Ombrophilous Montane Forest, Mixed Ombrophilous Montane Forest, and Semideciduos Montane Forest, highlighting endemic species such as Ferneseea itatiaiae, Piper itatiaianum, Itatiaia cleistopetala and Lycopodium jussiaei (IBDF 1982; ICMBio 2013). The fauna is diverse, with over 50,000 species of insects, 320 species of birds, 15 species of mammals, and 60 species of amphibians, including the Malanophryniscus moreirae, an endemic species chosen to be the symbol of the national park (IBAMA 1994; ICMBio 2013).

In hydrographic terms, the area is drained by Grande and Paraíba do Sul Basin Rivers, being the Itatiaia Alkaline Massif (IAM) its water divisor. According to the Köppen-Geiger climate classification, INP has the Cwb climate (mesothermic, mild summer and rainy season in summer) and Cpb climate (mesothermic, mild summer without dry season). Its average temperature is $11.4^{\circ} \mathrm{C}$, being January the warmest month $\left(13.6^{\circ} \mathrm{C}\right)$ and July the coldest $\left(8.2^{\circ} \mathrm{C}\right)(\mathrm{IBDF} 1982$; Tomzhinski 2012; ICMBio 2013).

Four soil classes were mapped by ICMBio (2013) dystric cambisol (humic), dystric litholic neosols, red-yellow dystric argisols, and latosols.

\subsection{Geological and Geomorphological Setting}

The INP has been the subject of geological and geomorphological research for decades (e.g. Silva 1876; Lasaulx 1885; Lamego 1936; Ab'Saber and Bernardes 1958; Penalva 1967; Modenesi and Melhem 1986; Brotzu et al. 1997; Melluso et al. 2017; Rosa and Ruberti 2018).

The study area is located in the interference zone between the structures related to two orogens, Brasília and Ribeira, in the Mantiqueira Province (Almeida et al. 1977, 1981), developed during the Brasiliano Pan-African Orogeny ( 670-480 Ma) as a result of the amalgamation of the West Gondwana Supercontinent (Heilbron et al. 2004). This period is also associated with large volumes of pre-, syn- and post-tectonic calcium-alkaline granites emplaced into the basement rocks (Trouw et al. 2003).

In the Upper Jurassic, the extensional tectonics, resulting from the South Atlantic Ocean's opening, allowed the reactivation of ancient faults and generation of tholeiitic basaltic magmatism ( 134 Ma) in the Paraná basin (Marques and Ernesto 2004; Thiede and Vasconcelos 2010). During the Meso-Cenozoic, the development of the Continental Rift of Southeastern Brazil (Riccomini 1989; Riccomini et al. 2004) reactivated the Brasiliano shear zones and allowed the intense alkaline magmatism of Serra do Mar Province and Cabo Frio Magmatic Lineament (Almeida 1983, 1991; Riccomini et al. 2004, 2005), including the intrusion of the IAM (e.g. Ribeiro Filho 1967; Penalva 1967; Brotzu et al. 1997; Enrich et al. 2005; Rosa 2017; Rosa and Ruberti 2018) and about 30 others alkaline bodies. During the Cenozoic, intense uplift, weathering and erosion processes occurred in the region, exposing outcrops of deep rocks, sculpting the landscape, and generating sediments that accumulated in the base of slopes, such as talus deposits, and depressed areas, such as alluvial deposits (Modenesi and Toledo 1993; Trouw et al. 2003; Zalán and Oliveira 2005; Cogné et al. 2012; Heilbron et al. 2016; Rosa and Ruberti 2018).

Regarding geomorphological aspects, Mantiqueira Mountain Range represents one of the highest orographic features (above 2,000m a.s.I.) on the Atlantic edge of the South American continent (Hiruma et al. 2010; Marques Neto et al. 2015). Its evolution is linked to the uplift that culminated in the formation of the Serra do Mar and Mantiqueira horsts; to the rifting processes that gave rise to the graben of Paraíba do Sul; and to the emplacement of alkaline rocks (Riccomini 1989; Almeida and Carneiro 1998; Zalán and Oliveira 2005; Marques Neto et al. 2015).

The INP is inserted in the morphostructural domain of the Neoproterozoic Mobile Belts and the geomorphological regions of the Paraíba do Sul Depression and Mantiqueira/Itatiaia Mountain Ranges (RADAMBRASIL 1983; IBGE 2009, 2019). The first is within the Middle Paraíba do Sul Depression unit, linked to the readjustment of regional tectonic movements and successive erosive and depositional phases. It is characterised by ridges, erosive scarps and valleys (RADAMBRASIL 1983). The latter is inserted in the Itatiaia Plateau unit, associated with tectonic activities, uplift and block failure in the NE-SW direction, represented by structural valleys, scarps, symmetrical ridges, and circular structures (IBGE 2009).

\section{Methodological Procedures}

The methodological procedures were structured into three main steps: the inventory of geosites, geodiversity sites and viewpoints, the analysis of the MP, and proposals for integrating the inventoried sites into the MP guidelines.

\subsection{Inventory of geological sites}

The inventory of geological sites (including geomorphological, hydrological, petrological, sedimentary, structural sites, etc.) was performed based on Brilha's $(2016,2018)$ concepts, which classifies as geosites only the high scientific relevance sites and as geodiversity sites the ones which relevance is mainly educational or recreative. It also included viewpoints, places that offer a view of rocks, structures, and landscapes with intrinsic value (Migoń and Pijet-Migoń 2017). It was carried out based on four steps:

(i) Definition of geological frameworks (GFs). This step was performed to identify and describe the main features related to the geology of the area. The GFs were defined based on the review of literature, interpretation of cartographic materials and suggestions of researchers who have conducted studies in the area. 
(ii) Selection of potential sites. It was carried out based on Mucivuna and Garcia (2017), which includes (a) review of literature; (b) analysis of the MP (IBDF 1982; ICMBio 2013); (c) review of tourist advertisement materials; (d) interviews with researchers who have worked in the area; (e) analysis of cartographic materials (geological map (Trouw et al. 2003; Heilbron et al. 2016; Rosa and Ruberti 2018), geomorphological and pedological maps (ICMBio 2013), satellite images (Google Earth ${ }^{\circledR}$, Global Digital Elevation Model) and Landsat 8 image (U.S. Geological Survey)), and (f) analysis of access routes and pathways.

(iii) Field evaluation. This step was performed intending to assess and describe potential sites, as well as identify new sites. Each of them was described in terms of its geological and geomorphological features, potential uses and threats.

(iv) Final list and characterisation of sites. Sites that (i) were not found in the fieldwork, (ii) were in inaccessible areas, or (iii) had no geoscientific importance were excluded from the final list. All potential geosites with scientific publications have been included in the final list because they are already recognised by the scientific community. As to those not mentioned in any publication, the criteria of representativeness, integrity and rarity were applied (Brilha 2016, 2018). Regarding geodiversity sites, the criteria of educational potential, variety of geological elements (educational value), scenery and interpretative potential (tourism value) were applied. The criteria of accessibility and safety (Brilha 2016, 2018) were not considered; since INP is a mountainous area, most sites are accessed only by hiking, and it has poor infrastructure.

\subsection{Analysis of the management plan}

In INP, two MP versions are available: the 1982 version covers its initial boundaries (IBDF 1982), and the current one includes the expanded area (ICMBio 2013). The analysis was performed based on the following aspects:

(i) Review of plans. This step was carried out in order to (i) identify potential sites that could be included in the inventory (item 4.1) and (ii) analyse the latest version (ICMBio 2013) considering the following questions:

- How are the elements of geodiversity described?

- Do geological and geomorphological maps show sites of geological interest?

- Is the physical characterisation of geological sites adequate?

- Do the proposals for public use cover sites of geological interest?

(ii) Diagnosis. All relevant information associated with geodiversity has been described and stored in a database.

(iii) Content analysis. The assessment was carried out based on how the information relating to geodiversity aspects was displayed in the MP.

\subsection{Proposals for integrating the inventoried sites into the management plan}

Based on the description of the previous steps, proposals to include geological sites in the management plan were performed based on the analysis of geodiversity content in the MP (item 5.2) and the inventory of geological sites (item 5.3).

\section{Results}

\subsection{Inventory of geological sites}

Six GF were defined (Table 1), represented by 17 geosites (Table 2 and Fig. 2). In addition, seven geodiversity sites (Table 3 and Fig. 3 ) and three viewpoints were also identified (Table 4 and Fig. 3). Figure 4 shows a map with the location of all inventoried sites.

The morphogenesis of the geosites are mainly associated with fluvial and mass movement processes (Quaternary deposits GL), tectonic reactivation (Cenozoic tectonism GF), intrusion and fracturing of alkaline rocks (first, second and third magmatic stages of alkaline intrusion GF), and metamorphic and ductile deformations (Proterozoic igneous and metamorphic rocks GF).

The distribution of these sites is not uniform in the territory; most of the inventoried sites are concentrated in the central region due to a high number of scientific publications, detailed mapping (scale 1:50.000), and excellent exposure of rock outcrops and relief features. In the south region there are less inventoried sites because of the dense Atlantic Forest cover and lacks geoscientific publications. The reduced number of sites in the north region is a result of the absence of rock outcrops since the igneous and metamorphic ones are quite weathered; therefore, the inventoried sites are only represented by waterfalls and hilltops. These are also a result of the distribution of the rocks in the park, since about $6 \%$ of the area is made up of alluvial and talus deposits of Quaternary age, $60 \%$ of alkaline rocks of Meso-Cenozoic age, and 34\% of igneous and metamorphic rocks of Proterozoic age (ICMBio 2013 ).

As for access, $82 \%$ of the sites are reached only by trails and their difficulty levels are considered moderate to high. Among them, $27 \%$ have a length of up to 2 $\mathrm{km}, 27 \%$ between 2.1 and $6.0 \mathrm{~km}, 9 \%$ between 6.1 and $10.0 \mathrm{~km}, 23 \%$ between 10.1 and $20.0 \mathrm{~km}$ and $14 \%$ over $20 \mathrm{~km}$.

Table 1

Description of the geological frameworks of the Itatiaia National Park, Brazil. 


\begin{tabular}{|c|c|c|}
\hline $\begin{array}{l}\text { Geological } \\
\text { Framework }\end{array}$ & Brief description & Geosites* \\
\hline \multirow[t]{4}{*}{$\begin{array}{l}\text { Quaternary } \\
\text { deposits }\end{array}$} & \multirow[t]{4}{*}{$\begin{array}{l}\text { It represents the geological, geomorphological and climatic processes that have controlled the evolution of the study } \\
\text { area's recent landforms. }\end{array}$} & $\begin{array}{l}\text { (1) Bog of } \\
\text { Aiuruoca River }\end{array}$ \\
\hline & & $\begin{array}{l}\text { (2) Bog of Preto } \\
\text { River }\end{array}$ \\
\hline & & $\begin{array}{l}\text { (3) Fluvial } \\
\text { deposits of Lago } \\
\text { Azul }\end{array}$ \\
\hline & & $\begin{array}{l}\text { (4) Talus } \\
\text { deposits of Serra } \\
\text { Negra village }\end{array}$ \\
\hline \multirow[t]{2}{*}{$\begin{array}{l}\text { Cenozoic } \\
\text { tectonism }\end{array}$} & \multirow[t]{2}{*}{$\begin{array}{l}\text { It includes the Cenozoic tectonism records represented by the following structures: (i) NW-SE, corresponding to the } \\
\text { elongation of the massif; (ii) ENE-WSW, following the basement and the arrangement of the Continental Rift of } \\
\text { Southeast Brazil (CRSB); and (iii) W-E, more perceptible in the central sector of the IAM (Rosa and Ruberti 2018). }\end{array}$} & $\begin{array}{l}\text { (5) Structural } \\
\text { valley of Campo } \\
\text { Belo River }\end{array}$ \\
\hline & & $\begin{array}{l}\text { (6) Fault } \\
\text { escarpment of } \\
\text { Couto-Prateleiras } \\
\text { Hills }\end{array}$ \\
\hline \multirow{2}{*}{$\begin{array}{l}\text { Third } \\
\text { magmatic } \\
\text { stage of } \\
\text { alkaline } \\
\text { intrusion }\end{array}$} & \multirow[t]{2}{*}{$\begin{array}{l}\text { It includes nepheline syenite to trachyte, trachyte and two small bodies of basic rocks from the last magmatic } \\
\text { intrusion of the IAM, 67.5 Ma (Rosa, 2017; Rosa and Ruberti, 2018). }\end{array}$} & $\begin{array}{l}\text { (7) Biotite } \\
\text { monzonite } \\
\text { quarry }\end{array}$ \\
\hline & & $\begin{array}{l}\text { (8) Breccia of } \\
\text { Pedra Furada Hill }\end{array}$ \\
\hline \multirow{4}{*}{$\begin{array}{l}\text { Second } \\
\text { magmatic } \\
\text { stage of } \\
\text { alkaline } \\
\text { intrusion }\end{array}$} & \multirow[t]{4}{*}{$\begin{array}{l}\text { It represents nepheline syenite to quartz syenite, trachyte and a small granite body formed during the second } \\
\text { magmatic intrusion between } 69.65 \text { and } 68.65 \mathrm{Ma} \text { (Rosa 2017; Rosa and Ruberti } 2018) \text {. It also covers the peralkaline } \\
\text { facies, symbolised by the circular ridge, one of the most outlined geomorphological features on the Itatiaia Plateau. }\end{array}$} & $\begin{array}{l}\text { (9) Fracture } \\
\text { planes of Pedra } \\
\text { do Altar Hill }\end{array}$ \\
\hline & & $\begin{array}{l}\text { (10) Fluted } \\
\text { erosion of } \\
\text { Agulhas Negras } \\
\text { Hill }\end{array}$ \\
\hline & & $\begin{array}{l}\text { (11) Ovos da } \\
\text { Galinha boulders } \\
\text { and trachyte } \\
\text { dyke swarm }\end{array}$ \\
\hline & & $\begin{array}{l}\text { (12) Ring-dyke } \\
\text { on Itatiaia } \\
\text { Plateau }\end{array}$ \\
\hline $\begin{array}{l}\text { First } \\
\text { magmatic } \\
\text { stage of } \\
\text { alkaline } \\
\text { intrusion }\end{array}$ & $\begin{array}{l}\text { This framework includes records of nepheline syenite rocks from the first magmatic intrusion, aged } 71.26 \text { Ma (Rosa } \\
2017) \text { and mostly embedded in the CRSB (Riccomini 1989), but not strongly affected or deformed by its evolution } \\
\text { (Rosa and Ruberti 2018). }\end{array}$ & $\begin{array}{l}\text { (13) Waterfalls } \\
\text { of Campo Belo } \\
\text { River Basin }\end{array}$ \\
\hline \multirow[t]{4}{*}{$\begin{array}{l}\text { Proterozoic } \\
\text { igneous and } \\
\text { metamorphic } \\
\text { rocks }\end{array}$} & \multirow[t]{4}{*}{$\begin{array}{l}\text { Basement composes the Paleoproterozoic rocks of Juiz de Fora Domain and Neoproterozoic rocks of Andrelândia } \\
\text { Sequence (Occidental Terrane), related to the Trans-Amazonian Orogenic Cycle and the Brasiliano Pan-African Cycle. }\end{array}$} & $\begin{array}{l}\text { (14) } \\
\text { Leucogranite of } \\
\text { Pedra Grande Hill }\end{array}$ \\
\hline & & $\begin{array}{l}\text { (15) Tectonics } \\
\text { records of Rio } \\
\text { Preto Waterfalls }\end{array}$ \\
\hline & & $\begin{array}{l}(16) \\
\text { Metagranitoid of } \\
\text { Enamorados } \\
\text { Peak }\end{array}$ \\
\hline & & $\begin{array}{l}\text { (17) Mylonitic } \\
\text { gneiss of Santa } \\
\text { Clara Waterfall }\end{array}$ \\
\hline
\end{tabular}

Table 2

Geosites in the Itatiaia National Park. Interests are based on the categories adopted at the Brazilian scale and visible on GEOSSIT platform: GM: Geomorphological, HD: Hydrological, MT: Metamorphism, PE: Paleoenvironmental, PL: Plutonism, PT: Petrological, SD: Sedimentary, SF: Surface formations, TC: Tectonics (CPRM 2020). 


\begin{tabular}{|c|c|c|c|}
\hline Geosite & $\begin{array}{l}\text { Coordinates } \\
23 \mathrm{~K}(\mathrm{UTM} \\
\text { WGS-84) }\end{array}$ & Interests & Brief description \\
\hline \multicolumn{4}{|l|}{ Quaternary deposits } \\
\hline $\begin{array}{l}\text { (1) Bog of Aiuruoca } \\
\text { River }\end{array}$ & $\begin{array}{l}534151 / \\
7527107\end{array}$ & $\begin{array}{l}\text { SF, SD, } \\
\mathrm{HD}, \mathrm{GM}\end{array}$ & $\begin{array}{l}\text { Floodplain filled with peat sediments and one of the highest springs in Brazil (Teixeira and Linsker } \\
\text { 2007). On its Western side, alluvial deposits with granules and pebbles are observed in the central } \\
\text { and upper portion of the profile. }\end{array}$ \\
\hline $\begin{array}{l}\text { (2) Bog of Preto } \\
\text { River }\end{array}$ & $\begin{array}{l}536460 / / \\
7526460\end{array}$ & $\begin{array}{l}\text { SF, SD, } \\
\mathrm{HD}, \mathrm{GM}\end{array}$ & $\begin{array}{l}\text { Depressive area filled with alluvial deposits and the Spring of Preto River. A few metres from its left } \\
\text { bank, alluvial deposits of up to one-metre high were observed, with sub-rounded granules at the top } \\
\text { of the profile. }\end{array}$ \\
\hline $\begin{array}{l}\text { (3) Fluvial deposits } \\
\text { of Lago Azul }\end{array}$ & $\begin{array}{l}539736 / \\
7517208\end{array}$ & $\begin{array}{l}\text { HD, SD, } \\
\text { GM }\end{array}$ & $\begin{array}{l}\text { Natural pool inserted in an incised valley (middle course of Campo Belo River), filled with boulders } \\
\text { and cobbles along the riverbank, as well as pebbles, granules and sand deposited on its left bank. }\end{array}$ \\
\hline $\begin{array}{l}\text { (4) Talus deposits of } \\
\text { Serra Negra village }\end{array}$ & $\begin{array}{l}530929 / \\
7532340\end{array}$ & GM, SF & $\begin{array}{l}\text { Talus deposits composed of large rock fragments in clay to a sand-clay matrix (ICMBio 2013) with } \\
\text { convex tops and slopes. In lower regions, the exposed boulders are related to slope erosion. }\end{array}$ \\
\hline \multicolumn{4}{|l|}{ Cenozoic tectonism } \\
\hline $\begin{array}{l}\text { (5) Structural valley } \\
\text { of Campo Belo River }\end{array}$ & $\begin{array}{l}532716 / \\
7524651\end{array}$ & $\begin{array}{l}\text { GM, TC, } \\
\text { SF, SD, } \\
\text { HD, PE, } \\
\text { PL }\end{array}$ & $\begin{array}{l}\text { Structural valley oriented in the NW-SE direction and segmented into six sub-areas including spring, } \\
\text { peat, talus and colluvium deposits, linear concentration of boulders, waterfall and a microalaskite } \\
\text { outcrop. }\end{array}$ \\
\hline $\begin{array}{l}\text { (6) Fault escarpment } \\
\text { of Couto-Prateleiras } \\
\text { Hills }\end{array}$ & $\begin{array}{l}532843 / \\
7524000\end{array}$ & $\begin{array}{l}\mathrm{GM}, \mathrm{TC} \\
\mathrm{PL}\end{array}$ & $\begin{array}{l}\text { Fault scarp oriented towards N70W (Penalva 1967) with rounded tops and straight slopes. It } \\
\text { comprises four sub-areas on Itatiaia Plateau such as Índio cave, hills (Couto and Prateleiras) and } \\
\text { boulders (Pedra da Maçã and Pedra da Tartaruga). }\end{array}$ \\
\hline \multicolumn{4}{|c|}{ Third magmatic stage of alkaline intrusion } \\
\hline $\begin{array}{l}\text { (7) Biotite monzonite } \\
\text { quarry }\end{array}$ & $\begin{array}{l}526016 / \\
7526458\end{array}$ & PT, PL & $\begin{array}{l}\text { Quarry composed of greenish-grey with medium-grained massive crystals, a significant amount of } \\
\text { poikilitic biotite, cleavage planes and no preferential orientation (Rosa and Ruberti 2018). }\end{array}$ \\
\hline $\begin{array}{l}\text { (8) Breccia of Pedra } \\
\text { Furada Hill }\end{array}$ & $\begin{array}{l}528365 / \\
7527402\end{array}$ & $\begin{array}{l}\mathrm{PT}, \mathrm{PL}, \\
\mathrm{GM}\end{array}$ & $\begin{array}{l}\text { Trachyte hill marked by fracture planes, top and smooth convex slopes. Some outcrops have fluidal } \\
\text { textures with deformed fragments along the trail to reach it, suggesting subvolcanic conduct } \\
\text { magmatism with intense activity. }\end{array}$ \\
\hline \multicolumn{4}{|c|}{ Second magmatic stage of alkaline intrusion } \\
\hline $\begin{array}{l}\text { (9) Fracture planes of } \\
\text { Pedra do Altar Hill }\end{array}$ & $\begin{array}{l}533539 / \\
7525715\end{array}$ & $\begin{array}{l}\text { TC, PL, } \\
\text { GM }\end{array}$ & $\begin{array}{l}\text { Intensely fractured hill, with uneven surfaces, smooth convex top and straight slopes. Vertical and } \\
\text { sub-vertical fracture planes are arranged on slopes and pitted erosion is observed on the ridge. }\end{array}$ \\
\hline $\begin{array}{l}\text { (10) Fluted erosion of } \\
\text { Agulhas Negras Hill }\end{array}$ & $\begin{array}{l}534818 / \\
7525059\end{array}$ & $\begin{array}{l}\mathrm{PT}, \mathrm{TC} \\
\mathrm{GM}\end{array}$ & $\begin{array}{l}\text { Deeply dissected hill with uneven surfaces, sharp peaks and straight slopes. There are fluted and } \\
\text { pitted erosion on fracture planes in the E-W direction formed by chemical dissolution due to } \\
\text { microorganisms associated with water. }\end{array}$ \\
\hline $\begin{array}{l}\text { (11) Ovos da Galinha } \\
\text { boulders and } \\
\text { trachyte dyke swarm }\end{array}$ & $\begin{array}{l}535060 / \\
7526810 \\
534929 / \\
7526795\end{array}$ & $\begin{array}{l}\mathrm{PL}, \mathrm{TC} \\
\mathrm{GM}\end{array}$ & $\begin{array}{l}\text { It includes two sub-areas: (i) five boulders arranged on a hill and aligned in the NW-SE direction, and } \\
\text { (ii) biotite hornblende pulaskite slab crosscut by trachyte dykes. }\end{array}$ \\
\hline $\begin{array}{l}\text { (12) Ring-dyke on } \\
\text { Itatiaia Plateau }\end{array}$ & $\begin{array}{l}536870 / \\
7528573\end{array}$ & $\begin{array}{l}\mathrm{PT}, \mathrm{PL}, \\
\mathrm{GM}\end{array}$ & $\begin{array}{l}\text { Circular crest marked by water gaps developed by river erosion. Maromba and Aiuruoca Rivers are } \\
\text { the most outstanding examples of these features (Teixeira 1961). }\end{array}$ \\
\hline \multicolumn{4}{|c|}{ First magmatic stage of alkaline intrusion } \\
\hline \multirow{4}{*}{$\begin{array}{l}\text { (13) Waterfalls of } \\
\text { Campo Belo River } \\
\text { Basin }\end{array}$} & $\begin{array}{l}538868 / / \\
7520001\end{array}$ & $\begin{array}{l}\mathrm{HD}, \mathrm{SF} \\
\mathrm{TC}, \mathrm{GM}\end{array}$ & $\begin{array}{l}\text { Waterfalls located in the Campo Belo and Maromba rivers with straight to convex slopes and } \\
\text { fragments of rocks deposited along their valleys. }\end{array}$ \\
\hline & $\begin{array}{l}539302 / / \\
7519893\end{array}$ & & \\
\hline & $\begin{array}{l}539161 / \\
7519592\end{array}$ & & \\
\hline & $\begin{array}{l}539774 / \\
7518369\end{array}$ & & \\
\hline \multicolumn{4}{|c|}{ Proterozoic igneous and metamorphic rocks } \\
\hline $\begin{array}{l}\text { (14) Leucogranite of } \\
\text { Pedra Grande Hill }\end{array}$ & $\begin{array}{l}529562 / / \\
7529067\end{array}$ & $\begin{array}{l}\mathrm{PL}, \mathrm{TC} \\
\mathrm{GM}\end{array}$ & $\begin{array}{l}\text { Convex top and slopes hill marked by stretched K-feldspar crystals and intrusions of quartz veins } \\
\text { discordant with foliation. }\end{array}$ \\
\hline $\begin{array}{l}\text { (15) Tectonics } \\
\text { records of Rio Preto } \\
\text { Waterfalls }\end{array}$ & $\begin{array}{l}539405 / \\
7530390 \\
539420 / \\
7530346\end{array}$ & $\begin{array}{l}\text { TC, MT, } \\
\text { HD, GM }\end{array}$ & $\begin{array}{l}\text { It includes two sub-areas: (i) slide waterfall composed of locally garnet-bearing banded paragneiss, } \\
\text { showing axial plane foliation to isoclinal to tight folds, and (ii) cascade marked by banded } \\
\text { paragneiss with moderate to high dip angle. }\end{array}$ \\
\hline $\begin{array}{l}\text { (16) Metagranitoid of } \\
\text { Enamorados Peak }\end{array}$ & $\begin{array}{l}526108 / \\
7525221\end{array}$ & $\begin{array}{l}\text { MT, GM, } \\
\text { TC }\end{array}$ & $\begin{array}{l}\text { Hill marked by an outcrop of about } 30 \text { metres at its top, with uneven surfaces and straight slopes. } \\
\text { Its foliation is oriented in the NW-SE direction, and the fracture planes are concordant with a } \\
\text { moderate dip angle. }\end{array}$ \\
\hline $\begin{array}{l}\text { (17) Mylonitic gneiss } \\
\text { of Santa Clara } \\
\text { Waterfall }\end{array}$ & $\begin{array}{l}541600 / / \\
7532273\end{array}$ & $\begin{array}{l}\text { MT, TC, } \\
\text { HD, GM }\end{array}$ & $\begin{array}{l}\text { Slide waterfall characterised by mylonitic gneiss with horizontal fracture planes, deformed feldspar } \\
\text { crystals and foliation orientated in the NW-SE direction. }\end{array}$ \\
\hline
\end{tabular}


Table 3

Geodiversity sites in the Itatiaia National Park. Interests are based on the categories adopted at the Brazilian scale and visible on GEOSSIT platform: GM: Geomorphological, HD: Hydrological, HG: Hydrogeological, MT: Metamorphism, PL: Plutonism, PT: Petrological, SD: Sedimentary, SF: Surface formations, TC:

Tectonics (CPRM 2020).

\begin{tabular}{|llll|}
\hline Geodiversity site & $\begin{array}{l}\text { Coordinates 23 K } \\
\text { (UTM WGS-84) }\end{array}$ & Interests & Brief description \\
\hline $\begin{array}{l}\text { (18) Lakes and wetlands with } \\
\text { peat deposits }\end{array}$ & $531616 / 7526418$ & $\begin{array}{l}\text { SF, SD, } \\
\text { HG, GM }\end{array}$ & $\begin{array}{l}\text { Wetland filled with peat deposits and shallow lakes surrounded by steep hills and } \\
\text { rocky peaks. }\end{array}$ \\
\hline $\begin{array}{l}\text { (19) Breccia of Camelo Hill } \\
\text { (20) Pitted erosion of Pedra }\end{array}$ & $534737 / 7526045$ & $\begin{array}{l}\text { PL, GM, } \\
\text { TC }\end{array}$ & $\begin{array}{l}\text { Hill marked by uneven surfaces, smooth convex top, straight slopes and chemical } \\
\text { dissolution in the fracture planes. }\end{array}$ \\
$\begin{array}{l}\text { (21) Aiuruoca Waterfall } \\
\text { and alveolar hollows. }\end{array}$ & $534128 / 7527224$ & $\begin{array}{l}\text { PL, TC, } \\
\text { HD, GM }\end{array}$ & $\begin{array}{l}\text { Cascade characterised by horizontal fracture planes and natural pool filled with } \\
\text { rock fragments. }\end{array}$ \\
$\begin{array}{l}\text { (22) Nepheline syenite of Três } \\
\text { Picos Hill }\end{array}$ & $542910 / 7519982$ & GM, PL & $\begin{array}{l}\text { Hill marked by convex top and slopes and an outcrop of about two metres long by } \\
\text { one metre wide on its ridge. }\end{array}$ \\
\hline $\begin{array}{l}\text { (23) Granitic gneiss of } \\
\text { Alcantilado Waterfall }\end{array}$ & $545202 / 7534632$ & $\begin{array}{l}\text { PL, TC, } \\
\text { HD, GM }\end{array}$ & $\begin{array}{l}\text { Cascade characterised by foliation in the NW-SE direction and moderate dip } \\
\text { angle. }\end{array}$ \\
\hline $\begin{array}{l}\text { (24) Gneiss of Cristais } \\
\text { Waterfall }\end{array}$ & $540397 / 7528736$ & $\begin{array}{l}\text { MT, TC, } \\
\text { HD, GM }\end{array}$ & $\begin{array}{l}\text { Tiered waterfall and a natural pool marked by locally folded rocks, foliation in the } \\
\text { NW-SE direction and low dip angle. }\end{array}$ \\
\hline
\end{tabular}

Table 4

Viewpoints in the Itatiaia National Park. Interests are based on the categories adopted at the Brazilian scale and visible on GEOSSIT platform: GM Geomorphological, HD - Hydrological, TC - Tectonics (CPRM 2020).

\begin{tabular}{|llll|}
\hline Viewpoint & $\begin{array}{l}\text { Coordinates 23 K } \\
\text { (UTM WGS-84) }\end{array}$ & Interests & Brief description \\
\hline $\begin{array}{l}\text { (25) Viewpoint } \\
\text { Flores Highway }\end{array}$ & $\begin{array}{l}528107 / \\
7526791\end{array}$ & GM, TC & $\begin{array}{l}\text { Visualisation of the Bocaina, Mantiqueira and Fina mountain ranges and Paraiba do Sul river } \\
\text { valley. }\end{array}$ \\
\hline $\begin{array}{l}\text { (26) Viewpoint } \\
\text { Ultimo Adeus }\end{array}$ & $\begin{array}{l}540414 / \\
7516328\end{array}$ & GM, TC, & $\begin{array}{l}\text { Panoramic view of the Campo Belo river's incised valley, Paraíba do Sul river valley, dam of Funil } \\
\text { hydroelectric power plant and Bocaina mountain range. }\end{array}$ \\
\hline $\begin{array}{l}\text { (27) Viewpoint } \\
\text { Alto dos Brejos } \\
\text { Hill }\end{array}$ & $539869 /$ & GM, TC & $\begin{array}{l}\text { Panoramic view of the Bocaina mountain range, Paraíba do Sul river valley, talus deposits, } \\
\text { asymmetric slopes, convex section slopes, Gavião peak and Pedra Selada protected area. }\end{array}$ \\
\hline
\end{tabular}

\subsection{Analysis of the management plan}

The main differences between the 1982 and 2013 plans are the size, as previously mentioned, and the applied methodological guidelines.

\subsubsection{2 plan}

Although the scope of this study's analysis is the latest version of the MP (ICMBio 2013), some aspects of the 1982 version are worth mentioning.

The 1982 version was developed by the Brazilian Institute for Forest Development, the institution that used to be responsible for park management, according to Decree No. 84,017/1979 (Brasil 1979). This Decree established general rules, which contained suggestions on the information that should be included in the MP, not imposing a specific technical requirement about its structure and writing. In this context, the 1982 plan has 207 pages and is divided in four chapters (i: national and regional context; ii: analysis of the protected area; iii: management and development, and; iv: implementing) that contains the area's description, zoning, and proposal for management actions (IBDF, 1982). This plan is no longer used by park managers.

The plan details the aspects of regional and local geological and geomorphological features. Some sites are emphasised (Viewpoint of Último Adeus, Lago Azul, Maromba Waterfall, Agulhas Negras Hill, Pedra do Altar Hill, Bog of Aiuruoca River) regarding the analysis of the landscape.

The document presents some management objectives directly associated with geodiversity, such as: (i) protect the springs; (ii) conserve areas of natural beauty in the Serra da Mantiqueira, and; (iii) provide visitors with environmental education and interpretation associated with high altitude grasslands, rivers, 
slopes and valleys. Moreover, it stresses that the most significant aspects of the Park's fauna, flora and geology must be considered in the development of interpretative trails. It also highlights that the geology and tectonics featured in the park represent an important heritage to be interpreted. Unfortunately, there is not any photo or local maps.

\subsubsection{3 plan}

The latest version (ICMBio 2013) was prepared by ECOMEK Business Consulting and Environment, a company commissioned by Chico Mendes Institute for Biodiversity Conservation (ICMBio). It was prepared based on the methodological planning guidelines of Galante et al. (2002), i.e., planning is a continuous and collaborative process. These guidelines are adjusted to the rules of NSPA and sets out that an MP must be organised in four reports, including (i) contextualisation of the protected area in the international, federal and state levels (three chapters); (ii) regional analysis of the municipalities covered by its boundaries (nine chapters); (iii) analysis of the biotic and abiotic characteristics, and the anthropic, cultural and institutional factors (nine chapters), and; (iv) planning strategies and its relation with the surroundings (seven chapters). The INP's MP characterises the area, draws and describes each zone's activities, and plans the management over 487 pages. Moreover, the plan is well illustrated with several regional and local maps.

Several chapters describe aspects of geodiversity that deserve attention (column 3: Table 5). In some of them, abiotic aspects are clearly mentioned, such as "to conserve areas of natural beauty representing Serra da Mantiqueira" and "provide visitors with environmental education and interpretation, such as highaltitude grasslands, rivers, slopes and valleys". In contrast, others are only indirectly mentioned (Table 5) or not even described (Visconde de Mauá region).

Several sites that have been inventoried in this work are mentioned in the document; however, only their potentials for tourism use are mentioned, with no consideration for their geological or geomorphological features.

Table 5

Analysis of the Itatiaia National Park management plan (ICMBio 2013). 


\begin{tabular}{|c|c|c|c|}
\hline Report & Chapter & Description of the management plan & $\begin{array}{l}\text { Analysis of the } \\
\text { description of } \\
\text { Geodiversity }\end{array}$ \\
\hline $\begin{array}{l}\text { Contextualisation } \\
\text { of the Itatiaia } \\
\text { National Park }\end{array}$ & State context & $\begin{array}{l}\text { Most management programmes and projects are focused on (i) conservation of biological } \\
\text { aspects, (ii) environmental education programmes, (iii) infrastructure building, and (iv) support } \\
\text { for creating protected areas within buffer zones. In addition, partner institutions can contribute } \\
\text { to research, environmental education and awareness projects, eco-tourism activities, and } \\
\text { tourist routes. }\end{array}$ & $\begin{array}{l}\text { It does not } \\
\text { mention the } \\
\text { conservation of } \\
\text { abiotic aspects, } \\
\text { nor describe } \\
\text { sites of } \\
\text { geological } \\
\text { interest that } \\
\text { could be } \\
\text { included in } \\
\text { environmental } \\
\text { education and } \\
\text { awareness } \\
\text { programmes. }\end{array}$ \\
\hline \multirow[t]{3}{*}{$\begin{array}{l}\text { Analysis of the } \\
\text { region of the } \\
\text { protected area }\end{array}$} & $\begin{array}{l}\text { Physical } \\
\text { Environment }\end{array}$ & $\begin{array}{l}\text { Regional physical aspects are described based on abiotic (Geology, Geomorphology, Soil, } \\
\text { Climate, Hydrography) and biotic (vegetation and fauna) characteristics. }\end{array}$ & $\begin{array}{l}\text { The description } \\
\text { is focused on } \\
\text { regional } \\
\text { aspects. }\end{array}$ \\
\hline & $\begin{array}{l}\text { Cultural and } \\
\text { historical } \\
\text { aspects }\end{array}$ & $\begin{array}{l}\text { Cultural and environmental heritages are described based on general aspects, location and } \\
\text { current uses. }\end{array}$ & $\begin{array}{l}\text { It includes sites } \\
\text { linked to } \\
\text { geodiversity, } \\
\text { such as peaks } \\
\text { and waterfalls. } \\
\text { However, they } \\
\text { are described } \\
\text { only in relation } \\
\text { to tourism } \\
\text { potential. }\end{array}$ \\
\hline & $\begin{array}{l}\text { Opportunities to } \\
\text { sustainable } \\
\text { economic } \\
\text { development }\end{array}$ & $\begin{array}{l}\text { The possibilities for strengthening the region are described through (i) infrastructure } \\
\text { construction, (ii) reforestation and (iii) tourism, mainly eco-tourism, involving local } \\
\text { communities. }\end{array}$ & $\begin{array}{l}\text { It does not offer } \\
\text { opportunities } \\
\text { for linking } \\
\text { environmental } \\
\text { aspects to local } \\
\text { communities. }\end{array}$ \\
\hline \multirow[t]{2}{*}{$\begin{array}{l}\text { Analysis of } \\
\text { Itatiaia National } \\
\text { Park }\end{array}$} & $\begin{array}{l}\text { Characterisation } \\
\text { of abiotic and } \\
\text { biotic aspects }\end{array}$ & $\begin{array}{l}\text { Specific abiotic (Climate, Geology, Geomorphology, Pedology, Hydrography) and biotic (Fauna } \\
\text { and Flora) aspects are highlighted through detailed descriptions, maps and figures. }\end{array}$ & $\begin{array}{l}\text { It describes the } \\
\text { main physical } \\
\text { aspects but } \\
\text { does not } \\
\text { assess the } \\
\text { threats and } \\
\text { degradation } \\
\text { risk. }\end{array}$ \\
\hline & $\begin{array}{l}\text { Statement of } \\
\text { significance }\end{array}$ & $\begin{array}{l}\text { Eleven aspects of relevance to protection are described, highlighting: (i) protect the } \\
\text { watersheds of the main hydrographic basins; (ii) enable scientific research focused on the } \\
\text { management of the area; (iii) conserve areas of natural beauty in Serra da Mantiqueira; (iv) } \\
\text { recover, preserve and protect the Itatiaia Plateau; (v) provide visitors with environmental } \\
\text { education and interpretation information, associated with high altitude grasslands, rivers, } \\
\text { slopes and valleys. }\end{array}$ & $\begin{array}{l}\text { Geodiversity is } \\
\text { not highlighted } \\
\text { concerning its } \\
\text { importance for } \\
\text { research. }\end{array}$ \\
\hline \multirow[t]{3}{*}{$\begin{array}{l}\text { Itatiaia National } \\
\text { Park Planning }\end{array}$} & $\begin{array}{l}\text { Specific } \\
\text { management } \\
\text { goals of Itatiaia } \\
\text { National Park }\end{array}$ & $\begin{array}{l}\text { Three pillars support the park's objectives: (i) the NSPA; (ii) the specific objectives of its } \\
\text { creation, and; (iii) its specific knowledge. The latter stands out because rare species, historical, } \\
\text { archaeological or paleontological sites, ecosystems, geological and geomorphological } \\
\text { formations of scenic beauty are essential for management. The management plan has } 20 \\
\text { management goals, of which we highlight: (i) protection of the landscape and scenic beauty } \\
\text { of Paraiba do Sul's Valley and Serra da Mantiqueira; (ii) protection of springs; (iii) provision of } \\
\text { activities for the public use, education and environmental interpretation of the natural } \\
\text { environment; (iv) promote visits to population of the surrounding area to raise environmental } \\
\text { awareness of the importance of preserving the region; and (v) encouragement and } \\
\text { development of visiting and tourism activities as an opportunity to local economic } \\
\text { development. }\end{array}$ & $\begin{array}{l}\text { Despite } \\
\text { mentioning the } \\
\text { promotion of } \\
\text { abiotic } \\
\text { elements } \\
\text { through public } \\
\text { use, } \\
\text { environmental } \\
\text { education and } \\
\text { interpretation } \\
\text { activities, there } \\
\text { is no project in } \\
\text { progress. }\end{array}$ \\
\hline & $\begin{array}{l}\text { Strategic } \\
\text { evaluation of } \\
\text { Itatiaia National } \\
\text { Park }\end{array}$ & $\begin{array}{l}\text { It is necessary to implement environmental education and awareness programmes targeted at } \\
\text { visitors and neighbours, as natural resources, historical-cultural and environmental values are } \\
\text { largely unknown. }\end{array}$ & $\begin{array}{l}\text { It has no action } \\
\text { in practice that } \\
\text { includes abiotic } \\
\text { aspects in } \\
\text { environmental } \\
\text { education and } \\
\text { awareness } \\
\text { programmes. }\end{array}$ \\
\hline & Zoning & $\begin{array}{l}\text { Eight zones were mapped and described based on biotic, abiotic, land use and occupation } \\
\text { characteristics, as well as allowed or forbidden activities. }\end{array}$ & $\begin{array}{l}\text { There is no } \\
\text { clear definition } \\
\text { of the rules and } \\
\text { activities } \\
\text { regarding the } \\
\text { use and } \\
\text { management } \\
\text { of biotic and }\end{array}$ \\
\hline
\end{tabular}

Page 10/21 


\section{Proposals For Integrating The Inventoried Sites Into The Management Plan}

All INP's MP reports have geodiversity aspects that require attention. However, there is no concrete proposal for conserving or monitoring these aspects. In this context, the first step to be taken should be including the diagnosis in the MP (inventory of geological sites) to characterise and evaluate geological site values and potential uses. This data would support the planning of conservation and management actions to ensure that the geoheritage features and the processes that form them are protected.

Proposals were made to include geological sites in the MP guidelines, considering the MP chapters that describe geodiversity directly or indirectly (item 5.2.2).

In the "contextualisation of the park" report, many universities, research groups, and companies dedicated to studies on geoconservation could contribute to research development through systematic geoheritage inventories. These actions could bring significant contributions since many PAs lack these data. In INP, the chapter "state approach" should include geoconservation projects like they do for biodiversity. In addition, the inclusion of inventoried sites would ensure that geodiversity and biodiversity conservation are linked for nature conservation; it would enrich the content of environmental education programmes through a systemic approach to the environment.

In the "analysis of the region of the protected area" report, tourism activities could address the conservation of the environment as a whole. In INP, the chapter "physical environment" could include some key geosites, such as the Fluted erosion of Agulhas Negras Hill (10) and Tectonic records of Rio Preto Waterfalls (15), in order to illustrate the geological history of the region. The chapter "cultural and historical aspects" should include geological sites linked with other aspects of the region. The chapter "opportunities to sustainable economic development" should associate geoconservation with tourism activities to contribute to the achievement of the SDGs. The dissemination of geoscientific content through Geotourism would be an excellent opportunity to contribute to the sustainable economic development of the region.

In the "analysis of the protected area" report, geoscientific content targeted at the general public and the population of the surrounding areas could be inserted to raise awareness of the role of geodiversity and geoconservation, to help reduce the negative aspects of biodiversity loss and to mitigate and adapt to climate change (Crofts et al. 2021). Furthermore, including such content in interpretation and environmental educational activities would contribute to the management and popularization of geological sites. Such actions could be implemented through leaflets, digital media, interpretative panels, etc. (Mucivuna and Garcia, 2018). The development of Geoscience courses for environmental guides could be an opportunity for the economic development of the region and contribute to the dissemination of scientific knowledge, as proposed in the MP. In INP, the chapter "characterising the abiotic and biotic aspects" should integrate geological sites to identify the priority of conservation actions and guarantee their conservation and management. In the chapter "statement of significance", geosites that have watersheds, such as Bogs of Aiuruoca and Preto Rivers (1 and 2), are essential to the protection of local freshwater. Viewpoints (25-27) and geodiversity sites (18-24) would allow a more integrated approach to environmental education and interpretation.

In the "planning" report, the geological sites located in zones that allow environmental interpretation, visiting, research, etc. should be assessed to check their potential use. In INP, the chapter "specific goals of management" should include the inventoried sites in the interpretation and environmental education projects to disseminate their importance for the management and conservation of the park. In the chapter "strategic evaluation", activities focused on the dissemination of abiotic aspects could be carried out combined with other values, such as the geosite Biotite monzonite quarry (7), which shows a significant relationship with the historical value, as the quarry rocks were used for the construction of some buildings. In the chapter "zoning", the assessment of the use of inventoried sites was performed to help their management in their respective park areas (Table 6).

Furthermore, the inventoried sites are related to some of the objectives described in the MP, as they could be used to increase awareness of the importance of conservation among visitors and the population of the surrounding areas; interpretation and education could contribute to the sustainable management of resources and raise awareness of the importance of PAs, in addition to highlighting the fundamental role of geological sites in the maintenance of ecosystems and the benefits provided by nature to society and developing a more sustainable future.

Since most of the inventoried sites are already used as a tourism attraction, their integration into the MP must be appropriately addressed by management staff in order to contribute to the development of geotourism and thus achieve the SDGs, notably SDG1 (no poverty) and SDG8 (decent work and economic growth).

Therefore, as the MP is both a source of data and a tool for managers, integrating geological sites into PA management would help managers ensure that important geological and geomorphological features are included in key nature management decisions, including biotic and abiotic aspects.

Table 6

Proposals for including the inventoried sites into the management plan based on the zoning and allowed activities. 


\begin{tabular}{|c|c|c|c|}
\hline Zoning & Allowed activities & $\begin{array}{l}\text { Inventoried } \\
\text { sites (Fig. } \\
4 \text { ) }\end{array}$ & Possibilities to include the inventoried sites into the management plan \\
\hline $\begin{array}{l}\text { Primitive zone: slight or minimal } \\
\text { human intervention, containing fauna } \\
\text { and flora species or natural } \\
\text { phenomena of great scientific value. }\end{array}$ & $\begin{array}{l}\text { Research, traditional } \\
\text { climbing, low } \\
\text { impact visits, hiking, } \\
\text { management, and } \\
\text { environmental } \\
\text { interpretation. }\end{array}$ & $\begin{array}{l}1,2,5,6,8 \\
9,10,11 \\
12,13,14 \\
15,16,17 \\
18,19,20 \\
21 \text { and } 24\end{array}$ & $\begin{array}{l}\text { Visiting geological sites can be an opportunity for developing tourism in } \\
\text { the region (Opportunities for sustainable economic development). In this } \\
\text { sense, the geosite Fluted erosion of Agulhas Negras Hill is an excellent } \\
\text { venue for understanding the physical environment, as it is already widely } \\
\text { used in traditional climbing. }\end{array}$ \\
\hline $\begin{array}{l}\text { Temporary Occupation Zone: area with } \\
\text { a concentration of residences and } \\
\text { areas of use. }\end{array}$ & $\begin{array}{l}\text { Protection, } \\
\text { environmental } \\
\text { interpretation and } \\
\text { awareness of the } \\
\text { local population. }\end{array}$ & 4 and 23 & $\begin{array}{l}\text { Projects aiming to promote environmental awareness and spread the } \\
\text { importance of preserving the region to neighbouring populations could } \\
\text { be included in specific management goals. Therefore, inventoried sites } \\
\text { close to the park boundaries are in a privileged location for the dialogue } \\
\text { between the park management and the local people. }\end{array}$ \\
\hline $\begin{array}{l}\text { Recovery Zone: areas with } \\
\text { considerable human impact. }\end{array}$ & $\begin{array}{l}\text { Protection, } \\
\text { environmental } \\
\text { interpretation and } \\
\text { awareness of the } \\
\text { local population, } \\
\text { visiting and } \\
\text { research. }\end{array}$ & 27 & $\begin{array}{l}\text { The integration of historical and geological values could be integrated } \\
\text { into the strategic evaluation section. In addition, the viewpoint has a } \\
\text { good potential for interpretation and environmental awareness of the } \\
\text { local population since residents use its path to transport local handmade } \\
\text { products. }\end{array}$ \\
\hline $\begin{array}{l}\text { Extensive Use Zone: mostly comprised } \\
\text { of natural areas, it may have signs of } \\
\text { anthropic activities. }\end{array}$ & $\begin{array}{l}\text { Visiting, research, } \\
\text { protection, } \\
\text { monitoring, } \\
\text { environmental } \\
\text { education and } \\
\text { awareness. }\end{array}$ & $\begin{array}{l}1,2,3,5,6 \\
9,10,11 \\
12,13,14 \\
16,18,20 \\
21,22,26 \\
\text { and } 27\end{array}$ & $\begin{array}{l}\text { An integrated environmental education programme, including biological } \\
\text { and geological aspects, could be included in the management plan } \\
\text { (State approach). The geosite Fluvial deposits of Lago Azul could } \\
\text { contribute to a better visitor experience. }\end{array}$ \\
\hline $\begin{array}{l}\text { Intensive Use Zone: comprised of } \\
\text { natural or anthropic areas, with the } \\
\text { environment maintained as close as } \\
\text { possible to nature. Infrastructures, } \\
\text { other facilities and services support } \\
\text { public use. }\end{array}$ & $\begin{array}{l}\text { Protection, research, } \\
\text { visiting, and } \\
\text { permanent } \\
\text { environmental } \\
\text { education activities. }\end{array}$ & $\begin{array}{l}5,7,8,13 \\
25 \text { and } 26\end{array}$ & $\begin{array}{l}\text { Stimulating scientific research could contribute to manage geological } \\
\text { and biological aspects (Statement of significance). The geosite } \\
\text { Structural valley of Campo Belo River is an excellent example of } \\
\text { scientific research on geological and biological aspects. }\end{array}$ \\
\hline
\end{tabular}

\section{Discussion}

\subsection{Inventory of geological sites}

Protected areas have among their objectives scientific research, educational and recreational activities. The INP stands out for the large amount of research and visits, receiving nearly 18,000 students on school trips and over 127,000 visitors in 2019 (ICMBio 2019, 2021).

Most of its tourist attractions have geodiversity elements of interest. Therefore, the development of a systematic inventory was considered an tool essential to support conservation and improve the way people are introduced to geodiversity elements.

Pica et al. (2017), Clivaz and Reynard (2018), Queiroz et al. (2019) and Reverte et al. (2019) highlight that natural processes or anthropogenic activities can destroy not-sufficiently protected or known geosites due to farming, quarrying, infrastructure construction, urbanisation, vandalism, weathering and others. Thus, assessing the physical environment's potential and restrictions and the impacts from its inappropriate use (Pfaltzgraff and Peixoto 2010 ) is fundamental to the conservation and integration of abiotic aspects in nature conservation policies (Garcia et al. 2019b).

Most of the INP's inventoried sites can only be reached by long trails that have high to moderate difficulty levels. Fortunately, there is no link between access difficulty and potential for using the site in educational programme. For example, mountainous areas are not only accessible by climbers, hikers, and trekking specialists, as the viewpoints Último Adeus and Flowers Highway can be accessed by motorised vehicles, offer a view to areas with exceptional geomorphological features and are excellent candidates to be used as educational resources (Mucivuna and Garcia 2018). In contrast, some sites that are difficult to access may limit the obtaining of geological information for research or dissemination of content. In this sense, virtual products could be excellent tools in the scientific study of relevant geosites as well as in providing new opportunities to experience and reveal the values of geodiversity by promoting geoheritage (Santos et al. 2018; Gordon et al. 2021; Ibanez et al. 2021). Furthermore, virtual products such as those developed for the Jaraguá State Park can be used as a model to promote geological sites in Brazilian PAs (https://geohereditas.igc.usp.br/passeio-virtual-PEJ/passeio-virtual_PEJ.html).

The number of tourists has increased exponentially in Brazilian PAs. In 2019, they received over 15.3 million visitors, the National Park and the National Forest categories being the most prominent. However, although many Brazilian PAs are nationally or internationally recognised for their geoheritage, there is not yet any systematic government action to conserve and manage abiotic aspects.

Taking an inventory of geological sites could be the initial step towards the preparation of the material to support the inclusion of geological sites in the MP.

\subsection{Analysis of the management plan and proposals for integrating the inventoried sites into its guidelines}


The MPs review showed how these documents have been prepared over the years. The 1982 version was prepared directly by the institution responsible for managing the INP and written in a context when geoheritage was not a topic of discussion at the international level. Despite this, a concern was noted for describing the elements of geodiversity and their importance for landscape analysis (even briefly), highlighting the importance of interpreting the park's geoheritage (even though not using the current concept). The 2013 version was developed by an outsourced company that is not responsible for its management and written in a context that the interest in geodiversity and geoconservation had grown in Brazil and around the world. The sites which had their geodiversity elements described were mostly those that are already widely visited and mainly referred to their potential for public use. Although research on geoconservation had already been published at that time, the INP MP did not address the conservation of abiotic elements.

The fact that the geodiversity elements in the study area's MP are addressed only briefly is not restricted only to the INP. Although the inclusion of geodiversity and geological setting is encouraged by the Ministry of Environment (Meira et al. 2018), the items that address them in Brazilian MPs are not very elaborated (Garcia et al. 2019a). Therefore, integrating these sites into the PA management is crucial to prevent significant geoscientific sites from being degraded due to the lack of knowledge by managers and visitors and to plan adequate geoconservation actions.

A systematic inventory of geological sites would be a reliable source for including and managing these sites. After analyzing the MP, not much geoheritage content was found; therefore, this gap should be filled. As the MP is a document that must be revised every five years, or even when new and relevant facts require it (Galante et al. 2002), the integration of the geological sites and geodiversity, as a whole, could be performed gradually according to the recommendation proposed herein.

Similar actions have achieved significant results in state-level PA along the coast of the state of São Paulo State, Brazil. Based on the geoheritage inventory of the state of São Paulo (Garcia et al. 2018), the inventoried geosites were integrated into the MP of the Central Coast Marine Environmental Protection Area, in the Geobiodiversity Protection Zone (Garcia et al. 2019c; MA 2019), demonstrating the crucial role of the geoheritage inventory to include geosites in local environmental policies. In addition, the geoheritage inventory of the municipality of Bertioga-SP (Mucivuna 2016) was also used as a basis for the inclusion of geosites and geodiversity sites in the MP of the Restinga de Bertioga State Park.

\section{Conclusions}

Many geoheritage inventories have been conducted in Brazilian PA in recent years (Meira et al. 2018; Mucivuna et al. 2021) and are evidences of the growth and development in geoconservation research. However, actions to ensure their conservation, management and use are still scarce.

The application of a systematic method and the evaluation of values according to park activities are helpful, as the set of geosites includes all events of local geological history. The MP has an essential role because it is a source of park-specific data and shows the possibilities of a direct tool for conserving and managing geological sites.

The INP has an approach strongly associated with geodiversity, being a key place for mountaineering activities. However, abiotic aspects do not receive the same attention as biodiversity, as shown by the MP analysis. More than just recognising the geological sites in the PA, the proposal to integrate them into the MP proved to be very promising for providing conservation possibilities to managers.

The integration of geological sites into local policies is in line with conservation and management policies proposed by IUCN (Crofts et al. 2020).

Finally, this work is aimed to support the analysis of other MPs. We expect that future Brazilian MPs include a better integration of geodiversity, biodiversity and landscape management into their contents during their preparation or revision.

\section{Declarations}

\section{Acknowledgements}

We thank Debora S. Queiroz, Eliana Mazzucato, Raquel M. M. Romão for their help during fieldwork and to the Itatiaia National Park for logistical support and research permissions.

\section{Funding Information}

This work was supported by the National Council for Scientific and Technological Development-CNPq [PhD scholarship no. 141970/2017-0] and the Coordination for the Improvement of Higher Education Personnel-CAPES [mobility scholarship no. 88881.189352/2018-0] granted to the first author. M. G. Garcia thanks the National Council for Scientific and Technological (CNPq), Grant 309964/2018-0.

\section{Conflicts of interest/Competing interests}

All authors certify that they have no affiliations with or involvement in any organization or entity with any financial interest or non-financial interest in the subject matter or materials discussed in this manuscript.

\section{Availability of data and material (data transparency)}


Not applicable

\section{Code availability (software application or custom code)}

Not applicable

\section{Additional declarations for articles in life science journals that report the results of studies involving humans and/or animals}

Not applicable

\section{Ethics approval (include appropriate approvals or waivers)}

Not applicable

\section{Consent to participate (include appropriate statements)}

Not applicable

\section{Consent for publication}

All authors agreed with the content and gave explicit consent to submit it.

\section{References}

1. Ab'Saber AN, Bernardes N (1958) Vale do Paraíba, Serra da Mantiqueira e arredores de São Paulo. International Congress of Geography 18:284-292

2. Almeida FFM (1983) Relações tectônicas das rochas alcalinas mesozoicas da região meridional da Plataforma Sul-Americana. Revista Brasileira de Geociências 13(3):139-158

3. Almeida FFM (1991) O Alinhamento Magmático de Cabo Frio. Proceedings of the Southeast Geology Symposium 2, 423-428

4. Almeida FFM, Carneiro CDR (1998) Origem e evolução da Serra do Mar. Revista Brasileira de Geociências 28(2):135-150

5. Almeida FFM, Hasui Y, Neves B, Fuck BB, R.A., 1977. Províncias estruturais brasileiras. Proceedings of the Northeast Geology Symposium 8, 363-391

6. Almeida FFM, Hasui Y, Neves B, Fuck BB, R.A (1981) Brazilian structural provinces: an introduction. Earth-Science Reviews 17(1-2):1-29. https://doi.org/10.1016/0012-8252(81)90003-9

7. Bétard F, Peulvast JP (2019) Geodiversity hotspots: concept, method and cartographic application for geoconservation purposes at regional scale. Environmental Management 63:822-834. https://doi.org/10.1007/s00267-019-01168-5

8. Brasil (1979) Decreto n 84.071 de 21 de setembro de 1979. http://www.planalto.gov.br/ccivil_03/Atos/decretos/1979/D84017.html (Accessed 15 jan 2021)

9. Brasil (1988) Constituição da República Federativa do Brasil. http://www.planalto.gov.br/ccivil_03/constituicao/constituicaocompilado.htm (Accessed 10 March 2017)

10. Brasil (2000) Lei $n^{\circ} 9.985$ de 18 de julho de 2000. http://www.planalto.gov.br/ccivil_03/leis/L9985.htm (acessed 25 November 2015)

11. Brilha J (2002) Geoconservation and protected areas. Environ Conserv 29(3):273-276

12. Brilha J (2016) Inventory and quantitative assessment of geosites and geodiversity sites: a review. Geoheritage 8(2):119-134. https://doi.org/10.1007/s12371-014-0139-3

13. Brilha J (2017) Trends and challenges for geoconservation. Geophysical Research Abstract 19:8626

14. Brilha J (2018) Geoheritage: inventories and evaluation. In: Reynard E, Brilha J (eds) Geoheritage: assessment, protection and management. Elsevier, Amsterdam, pp 69-85

15. Brilha J, Reynard E (2018) Geoheritage and Geoconservation: the challenges. In: Reynard E, Brilha J (eds) Geoheritage: assessment, protection and management. Elsevier, Amsterdam, pp 433-438

16. Brilha J, Gray M, Pereira DI, Pereira P (2018) Geodiversity: An integrative review as a contribution to the sustainable management of the whole of nature. Environmental Science Policy 86:19-28. https://doi.org/10.1016/j.envsci.2018.05.001

17. Brotzu P, Gomes CB, Melluso L, Morbidelli L, Morra V, Ruberti E (1997) Petrogenesis of coexisting $\mathrm{SiO}_{2}$-undersaturated to $\mathrm{SiO}_{2}$-oversaturated felsic igneous rocks: the alkaline complex of Itatiaia, southeastern Brazil. Lithos 40(2-4):133-156. https://doi.org/10.1016/S0024-4937(97)00007-8

18. Castro Júnior E, Coutinho BH, Freitas LE (2009) Gestão da Biodiversidade e áreas protegidas. In: Guerra AJT, Coelho MCN (Orgs.) Unidades de Conservação: abordagens e características geográficas. Bertrand, Rio de Janeiro, pp 25-65 
19. Clivaz M, Reynard E (2018) How to integrate invisible geomorphosites in an inventory: a case study in the Rhone River valley (Switzerland). Geoheritage 10(4):527-541. https://doi.org/10.1007/s12371-017-0222-7

20. Cogné N, Gallagher K, Cobbold PR, Riccomini C, Gautheron C (2012) Post-breakup tectonics in southeast Brazil from thermochronological data and combined inverse-forward thermal history modeling. Journal of Geophysical Research 117:B11413. https://doi.org/10.1029/2012JB009340

21. CPRM. Serviço Geológico do Brasil, 2020. GEOSSIT: cadastro de sítios geológicos. https://www.cprm.gov.br/geossit/geossitios (accessed May 2020)

22. Crofts R (2018) Putting geoheritage conservation on all agendas. Geoheritage 10:231-238. https://doi.org/10.1007/s12371-017-0239-y

23. Crofts R, Gordon JE (2014) Geoconservation in protected areas. Parks 20(2):61-76. https://doi.org/10.2305/IUCN.CH.2014.PARKS-20-2.RC.en

24. Crofts R, Gordon JE (2015) Geoconservation in protected areas. In: Worboys GL, Lockwood M, Kothari A, Feary S, Pulsford I (eds) Protected area governance and management. ANU Press, Canberra, pp 531-568

25. Crofts R, Gordon JE, Brilha J, Gray M, Gunn J, Larwood J, Santucci VL, Tormey D, Worboys GL (2020) Guidelines for geoconservation in protected and conserved areas: best practice protected area guidelines, series n. 31. IUCN, Gland

26. Crofts R, Tormey D, Gordon JE (2021) Introducing New Guidelines on Geoheritage Conservation in Protected and Conserved Areas. Geoheritage 13:33. https://doi.org/10.1007/s12371-021-00552-0

27. D’amico AR, Coutinho EO, Moraes LFP (2018) Roteiro metodológico para elaboração e revisão de planos de manejo das unidades de conservação federais. ICMBio - Instituto Chico Mendes de Conservação da Biodiversidade: Brasília

28. Díaz-Martínez E, Brilha J, Brocx M, Erikstad L, García-Cortés A, Wimbledon WAP (2016) Global Geosites: an active and partially achieved geoheritage inventory initiative, waiting to regain official recognition. In: Cornée A, Egoroff G, Wever P, Lalanne A, Duranthon F (eds) Actes du congrès international "Les inventaires du géopatrimoine". Mémoire hors-série de la Société géologique de France, Toulouse, pp 103-108

29. Díaz-Martínez E, Guillén-Mondéjar F, Brilha J, Monge-Ganuzas M, Herrero Martínez N, Hilario A, Mata-Perelló JM, Meléndez G, Utiel JC (2017) Nuevas resoluciones y avances de la UICN para la geoconservación. In: Carcavilla L, Duque-Macías J, Giménez J, Hilario A, Monge-Ganuzas M, Vegas J, Rodríguez A (eds) Patrimonio geológico, gestionando la parte abiótica del patrimonio natural. Cuadernos del Museo Geominero, Madrid, pp $247-252$

30. Dingwall PR (2000) Legislation and international agreements: the integration of the geological heritage in nature conservation policies. In: Barrentino $D$, Wimbledon WAP, Gallego E (eds) Geological heritage: its conservation and management. IGME, Madrid, pp 15-28

31. Dudley N (2008) Guidelines for applying protected area management categories. IUCN, Gland

32. Enrich GER, Azzone RG, Ruberti E, Gomes CB, Comin-Chiaramonti P (2005) Itatiaia, Passa Quatro and São Sebastião Island, the major alcaline syenitic complex from the Serra do Mar region. In: Comin-Chiaramonti P, Gomes CB (eds) Mesozoic to Cenozoic alkaline magmatism in the Brazilian Platform. EDUSP/FAPESP, São Paulo, pp 419-441

33. Galante MLV, Beserra MML, Menezes EO (2002) Roteiro metodológico de planejamento: Parque Nacional, Reserva Biológica, Estação Ecológica. IBAMA Instituto Brasileiro de Meio Ambiente e Recursos Naturais Renováveis, Brasília

34. Garcia MGM, Brilha J, Lima FF et al (2018) The inventory of geological heritage of the state of São Paulo, Brazil: methodological basis, results and perspectives. Geoheritage 10(2):239-258. https://doi.org/10.1007/s12371-016-0215-y

35. Garcia MGM, Reverte FC, Mucivuna VC, Arruda KEC, Prochoroff R, Santos PLA, Romão RMM (2019a) Geoconservação em áreas protegidas: contribuição de cursos para monitores ambientais no litoral norte do estado de São Paulo, Brasil. Terrae Didatica 15:e19028.

https://doi.org/10.20396/td.v15i0.8652390

36. Garcia MGM, Del Lama E, Martins L, Mazoca CEM, Bourotte CLM (2019b) Inventory and assessment of geosites to stimulate regional sustainable management: the northern coast of the state of São Paulo, Brazil. Anais da Academia Brasileira de Ciências. 91(2), e20180514.

https://doi.org/10.1590/0001-3765201920180514

37. Garcia MGM, Lanza MCT, Silva IL, Mucivuna VC, Costa JA, Queiroz DS (2019c) Geossítios como áreas de interesse em planos de manejo de unidades de conservação: exemplo da APA Marinha Litoral Centro, estado de São Paulo. Simpósio Brasileiro de Patrimônio Geológico 5:40-41

38. Gordon JE, Crofts R, Díaz-Martínez E (2018a) Geoheritage conservation and environmental policies: retrospect and prospect. In: Reynard E, Brilha J (eds) Geoheritage: assessment, protection and management. Elsevier, Amsterdam, pp 213-235

39. Gordon JE, Crofts R, Díaz-Martínez E, Woo KS (2018b) Enhancing the role of geoconservation in protected area management and nature conservation. Geoheritage 10:191-203. https://doi.org/10.1007/s12371-017-0240-5

40. Gordon JE, Crofts R, Gray M, Tormey D (2021) Including geoconservation in the management of protected and conserved areas matters for all of nature and people. International Journal of Geoheritage Parks. https://doi.org/10.1016/j.ijgeop.2021.05.003

41. Gray M (2004) Geodiversity: valuing and conserving abiotic nature. John Wiley \& Sons, Londres

42. Gray M (2013) Geodiversity: valuing and conserving abiotic nature. John Wiley \& Sons, Londres

43. Heilbron M, Pedrosa-Soares AC, Campos Neto MC, Silva LC, Trouw RAJ, Janasi VA (2004) Província Mantiqueira. In: Mantesso-Neto V, Bartorelli A, Carneiro CDR, Brito-Neves BB (eds) Geologia do Continente Sul-Americano: evolução da obra de Fernando Flávio Marques de Almeida. Beca, São Paulo, pp 203-234

44. Heilbron M, Eirado LG, Almeida J (2016) Mapa Geológico e de Recursos Minerais do Estado do Rio de Janeiro. Serviço Geológico do Brasil, scale 1:400.000

45. Henriques MH, Reis RP, Brilha J, Mota T (2011) Geoconservation as an emerging geoscience. Geoheritage 3:117-128. https://doi.org/10.1007/s12371011-0039-8

46. Hiruma ST, Riccomini C, Modenesi-Gauttieri MC, Hackspacher PC, Hadler-Neto JC, Franco-Magalhães AOB (2010) Denudation history of the Bocaina Plateau, Serra do Mar, southeastern Brazil: relationships to Gondwana breakup and passive margin development. Gondwana Research 8(4):674-687.

Page 15/21 
https://doi.org/10.1016/j.gr.2010.03.001

47. IBAMA. Instituto Brasileiro do Meio Ambiente e dos Recursos Naturais Renováveis (1994) Plano Emergencial para o Parque Nacional do Itatiaia. Diretoria de Ecossistemas, departamento de unidades de conservação, Brasília

48. Ibanez K, Garcia MGM, Mazoca CEM (2021) Tectonic geoheritage as records of Western Gondwana history: a study based on a geosite's potential in the central Ribeira Belt, Southeastern Brazil. Geoheritage 13:9. https://doi.org/10.1007/s12371-021-00533-3

49. IBDF. Instituto Brasileiro de Desenvolvimento Florestal (1982) Plano de manejo do Parque Nacional do Itatiaia. IBDF, Brasília

50. IBGE. Instituto de Geografia e Estatística, 2009. Manual técnico de Geomorfologia. IBGE, Rio de Janeiro

51. IBGE. Instituto Brasileiro de Geografia e Estatística, 2016. Anuário estatístico do Brasil. IBGE, Rio de Janeiro

52. IBGE. Instituto Brasileiro de Geografia e Estatística (2019) Base Vetorial Geomorfologia do Brasil. https://www.ibge.gov.br/geociencias/downloadsgeociencias.html (accessed January 2020)

53. ICMBio. Instituto Chico Mendes de Conservação da Biodiversidade, 2013. Plano de Manejo: Parque Nacional do Itatiaia. ICMBio, Brasília

54. ICMBio. Instituto Chico Mendes de Conservação da Biodiversidade, 2019. Monitoramento da visitação em Unidades de Conservação Federais: resultados de 2019 e breve panorâmica histórico.

https://www.icmbio.gov.br/portal/images/stories/comunicacao/publicacoes/monitoramento_visitacao_em_ucs_federais_resultados_2019_breve_panora (accessed 03 jan 2021)

55. ICMBio (2021) Instituto Chico Mendes de Conservação da Biodiversidade, Notas de pesquisa.

https://www.icmbio.gov.br/parnaitatiaia/images/stories/2021/o-que-fazemos/notas-de-pesquisa/433.pdf (accessed 20 feb 2021)

56. IUCN, International Union for Conservation of Nature (2016) The world now protects $15 \%$ of its land, but crucial biodiversity zones left out. https://www.iucn.org/news/secretariat/201609/world-now-protects-15-its-land-crucial-biodiversity-zones-left-out (accessed 18 August 2019)

57. Lamego AR (1936) O massiço de Itatiaya e regiões circumdantes. Boletim do Serviço Geológico e Mineralógico do. v. 88, 1-93

58. Lasaulx A, 1885. Üeber das Vorkommen von Eläeolith-Syeniten und editeri zu diesen gehöringen Eläeolith-porphyren aus der Serra d'Itatiaia westlich von Rio de Janeiro, Brasilien. Sitzungsberichte Der Niederrheinischen Gesellschaft Für Natur, 231-232

59. MA (2019) Minuta em aprovação do plano de manejo da APA Marinha Litoral Centro. http://sigam.ambiente.sp.gov.br (accessed 11 July 2019 )

60. Marques LS, Ernesto M (2004) O magmatismo toleítico da Bacia do Paraná. In: Neto M, Bartorelli V, Carneiro A, Brito-Neves CDR, B.B. (eds) Geologia do Continente Sul-Americano: Evolução da Obra de Fernando Flávio Marques de Almeida. Beca, São Paulo, pp 245-263

61. Marques Neto R, Perez Filho A, Oliveira TA (2015) Itatiaia Massif: morphogenesis of Southeastern Brazilian highlands. In: Vieira BC, Salgado AAR, Santos LJC (eds) Landscapes and landforms of Brazil. Springer, Berlin, pp 299-308

62. Martini G (1994) Actes du premier symposium international sur la protection du patrimoine géologique. Société Géologique de France, Paris

63. Matthews TJ (2014) Integrating Geoconservation and Biodiversity conservation: theoretical foundation and conservation recommendations in a European Union context. Geoheritage 6:57-70. https://doi.org/10.1007/s12371-013-0092-6

64. Medeiros R (2003) Proteção da natureza: das estratégias internacionais e nacionais às demandas locais. PhD Thesis, Federal University of Rio de Janeiro

65. Medeiros R (2006) Evolução das tipologias de áreas protegidas no Brasil. Ambiente sociedade 9(1):41-64. https://doi.org/10.1590/S1414$753 \times 2006000100003$

66. Medeiros R, Irving M, Garay I (2004) A proteção da natureza no Brasil: evolução e conflitos de um modelo em construção. Revista de Desenvolvimento Econômico 9:83-93

67. Meira SA, Nascimento MAL, Silva EV (2018) Unidades de Conservação e geodiversidade: uma breve discussão. Terr@Plural. 12(2), 166-187. https://doi.org/10.5212/TerraPlural.v.12i2.0002

68. Melluso L, Guarino V, Lustrino M, Morra V, De' Gennaro R (2017) The REE- and HFSE-bearing phases in the Itatiaia Alkaline Complex (Brazil), and geochemical evolution of feldspar-rich felsic melts. Mineral Mag 81(2):217-250. https://doi.org/10.1180/minmag.2016.080.122

69. Migoń P, Pijet-Migoń E (2017) Viewpoint geosites: values, conservation and management issues. Proceedings of the Geologists' Association 128(4), 511522. https://doi.org/10.1016/j.pgeola.2017.05.007

70. MMA. Ministério do Meio, Ambiente (2004) Portaria n 126, de 27 de maio de 2004. http://www.mma.gov.br/biodiversidade/biodiversidade-brasileira/ áreas-prioritárias (accessed 10 March 2017)

71. Modenesi MC, Melhem TS (1986) Primeiros resultados da palinologia dos sedimentos turfosos da várzea do Ribeirão das Flores, Itatiaia-Rio de Janeiro. Revista do Instituto Geológico 7(1-2):35-38. http://dx.doi.org/10.5935/0100-929X.19860005

72. Modenesi MC, Toledo MCM (1993) Morfogênese quaternária e intemperismo: colúvios do Planalto do Itatiaia. Revista do Instituto Geológico 14(1):4553. http://dx.doi.org/10.5935/0100-929X.19930004

73. Mucivuna VC (2016) Estratégias de geoconservação aplicadas à geodiversidade do município de Bertioga-SP e às fortificações do litoral paulista. Master's Dissertation, University of São Paulo

74. Mucivuna VC, Garcia MGM (2017) Método para seleção de potenciais geossítios e geomorfossítios do inventário do Parque Nacional de Itatiaia. Simpósio Brasileiro de Patrimônio Geológico 4:367-371

75. Mucivuna VC, Garcia MGM (2018) Educational and tourism use of easy-access viewpoints: a study in the Itatiaia National Park, Brazil. Proceedings of the Quadrennial Conference of the International Geoscience Education Organisation 8, 202-207

76. Mucivuna VC, Garcia MGM, Reynard E (2021) Criteria for assessing geological sites in national parks: a study in the Itatiaia National Park, Brazil. Manuscript submitted to Geoheritage

Page $16 / 21$ 
77. Myers N, Mittermeier RA, Mittermeier CG, Fonseca GAB, Kent J (2000) Biodiversity hotspots for conservation priorities. Nature 403:853-858. https://doi.org/10.1038/35002501

78. O'Halloran D, Green C, Harley M, Stanley M, Knill. J (1994) Geological and landscape conservation. The Geological Society, London

79. Panizza M (2001) Geomorphosites: concepts, methods and examples of geomorphological survey. Chin Sci Bull (suppl Bd) 46:4-6

80. Penalva F (1967) Geologia e Tectônica da Região do Itatiaia (Sudeste do Brasil). Boletim da Faculdade de Filosofia. Ciências e Letras 22:99-193. http://dx.doi.org/10.11606/issn.2526-3862.bffcluspgeologia.1967.121904

81. Pica A, Luberti GM, Vergari F, Fredi P, Del Monte M (2017) Contribution for an urban geomorphoheritage assessment method: proposal from three geomorphosites in Rome (Italy). Quaestiones Geographicae 36(3):21-36. https://doi.org/10.1515/quageo-2017-0030

82. Pfaltzgraff PAS, Peixoto CAB (2010) Introdução. In: Peixoto AB (Org.) Geodiversidade do Estado de São Paulo. CPRM, São Paulo, pp 9-4

83. Prosser CD (2013) Our rich and varied geoconservation portfolio: the foundation for the future. Proceedings of the Geologists' Association. 124(4), 568580. http://dx.doi.org/10.1016/j.pgeola.2012.06.001

84. Queiroz DS, Garcia MGM, Del Lama E (2019) Desafios para a avaliação de locais de interesse geológico em áreas urbanizadas: Baixada Santista, litoral do estado de São Paulo. Anuário do Instituto de Geociências-UFRJ. 42(3), 129-144. http://dx.doi.org/10.11137/2019_3_129_144

85. Projeto RADAMBRASIL RADAMBRASIL (1983) Levantamento de Recursos Naturais. In: Folha SF.23/24 Rio de Janeiro/Vitória: Geologia, Geomorfologia, Pedologia, Vegetação e Uso Potencial da Terra. Ministério de Minas e Energia, Rio de Janeiro

86. Reverte FC, Garcia MGM, Brilha J, Moura TT (2018) Inventário como instrumento de gestão e preservação da memória geológica: exemplo dos geossítios vulneráveis da Bacia de Taubaté-SP. Pesquisas em Geociências 46(1):e0779. https://doi.org/10.22456/1807-9806.93252

87. Reynard E, Brilha J (2018) Geoheritage: a multidisciplinary and applied research topic. In: Reynard E, Brilha J (eds) Geoheritage: assessment, protection and management. Elsevier, Amsterdam, pp 3-9

88. Reynard E, Coratza P, Regolini-Bissig G (eds) (2009) Geomorphosites. Pfeil, München

89. Ribeiro Filho E (1967) Geologia e Petrologia dos Maciços Alcalinos do Itatiaia e Passa-Quatro (Sudeste do Brasil). Boletim da Faculdade de Filosofia. Ciências e Letras 22:9-89. http://dx.doi.org/10.11606/issn.2526-3862.bffcluspgeologia.1967.121901

90. Riccomini C (1989) O Rift Continental do Sudeste do Brasil. PhD Thesis, University of São Paulo

91. Riccomini C, Sant'Anna LG, Ferrari AL (2004) Evolução geológica do Rift Continental do Sudeste do Brasil. In: Neto M, Bartorelli V, Carneiro A, Brito-Neves CDR, B.B. (eds) Geologia do Continente Sul-Americano. Evolução da Obra de Fernando Flávio Marques de Almeida. Beca, São Paulo, pp $383-405$

92. Riccomini C, Velázquez VF, Gomes CB (2005) Tectonic controls of the Mesozoic and Cenozoic alkaline magmatism in Central-Southeastern Brazilian Platform. In: Comin-Chiaramonti P, Gomes CB (eds) Mesozoic to Cenozoic alkaline magmatism in the Brazilian Platform. EDUSP/FAPESP, Sao Paulo, pp 31-55

93. Rosa PAS (2017) Geologia e evolução petrogenética do maciço alcalino de Itatiaia, MG-RJ. PhD Thesis, University of São Paulo

94. Rosa PAS, Ruberti E (2018) Nepheline syenites to syenites and granitic rocks of the Itatiaia Alkaline Massif, Southeastern Brazil: new geological insights into a migratory ring Complex. Brazilian Journal of Geology 48(2):347-372. https://doi.org/10.1590/2317-4889201820170092

95. Santos I, Henriques R, Mariano G, Pereira DI (2018) Methodologies to represent and promote the geoheritage using unmanned aerial vehicles, multimedia technologies, and augmented reality. Geoheritage 10:143-155. https://doi.org/10.1007/s12371-018-0305-0

96. Silva JF (1876) Descripção do Itatiaia ou Itatiaio. Revista do Instituto Histórico e Geográfico Brasileiro 39:413-418

97. Sharples C (2002) Concepts and principles of Geoconservation. http://www.parks.tas.gov. au/geo/conprin/define.html (accessed 10 March 2019)

98. Teixeira D (1961) Relevo e padrões de drenagem na chaminé vulcânica do Itatiaia. Boletim Paulista de Geografia 37:3-12

99. Teixeira W, Linsker R (2007) Itatiaia: Sentinela das Alturas. Terra Virgem, São Paulo

100. Thiede DS, Vasconcelos PM (2010) Paraná flood basalts: rapid extrusion hypothesis confirmed by new 40Ar/39Ar results. Geology 2010. 38 (8), 747750. https://doi.org/10.1130/G30919.1

101. Thomas MF (2012) Geodiversity and landscape sensitivity: a geomorphological perspective. Scottish Geographical Journal 128(3-4):195-210. https://doi.org/10.1080/14702541.2012.725863

102. Tomzhinski GW (2012) Análise geoecológica dos incêndios florestais no Parque Nacional do Itatiaia. Master's Dissertation, Federal University of Rio de Janeiro

103. Trouw RAJ, Ribeiro A, Paciullo FVP (2003) Geologia da Folha Pouso Alto 1:100.000. In: Soares P, Noce CA, Trouw MA, Heilbron RAJ, M. (eds) Geologia e Recursos Minerais do Sudeste Mineiro, Projeto Sul de Minas-Etapa I. Companhia Mineradora de Minas Gerais, Belo Horizonte

104. Woo KS (2017) Role of IUCN WCPA Geoheritage Specialist Group for geoheritage conservation and recognition of World Heritage Sites, Global Geoparks and other protected areas. Geophysical Research Abstracts 19:1137

105. Zalán PV, Oliveira JAB (2005) Origem e evolução estrutural do Sistema de Riftes Cenozoicos do Sudeste do Brasil. Boletim de Geociências da Petrobras 13(2):296-300

\section{Figures}




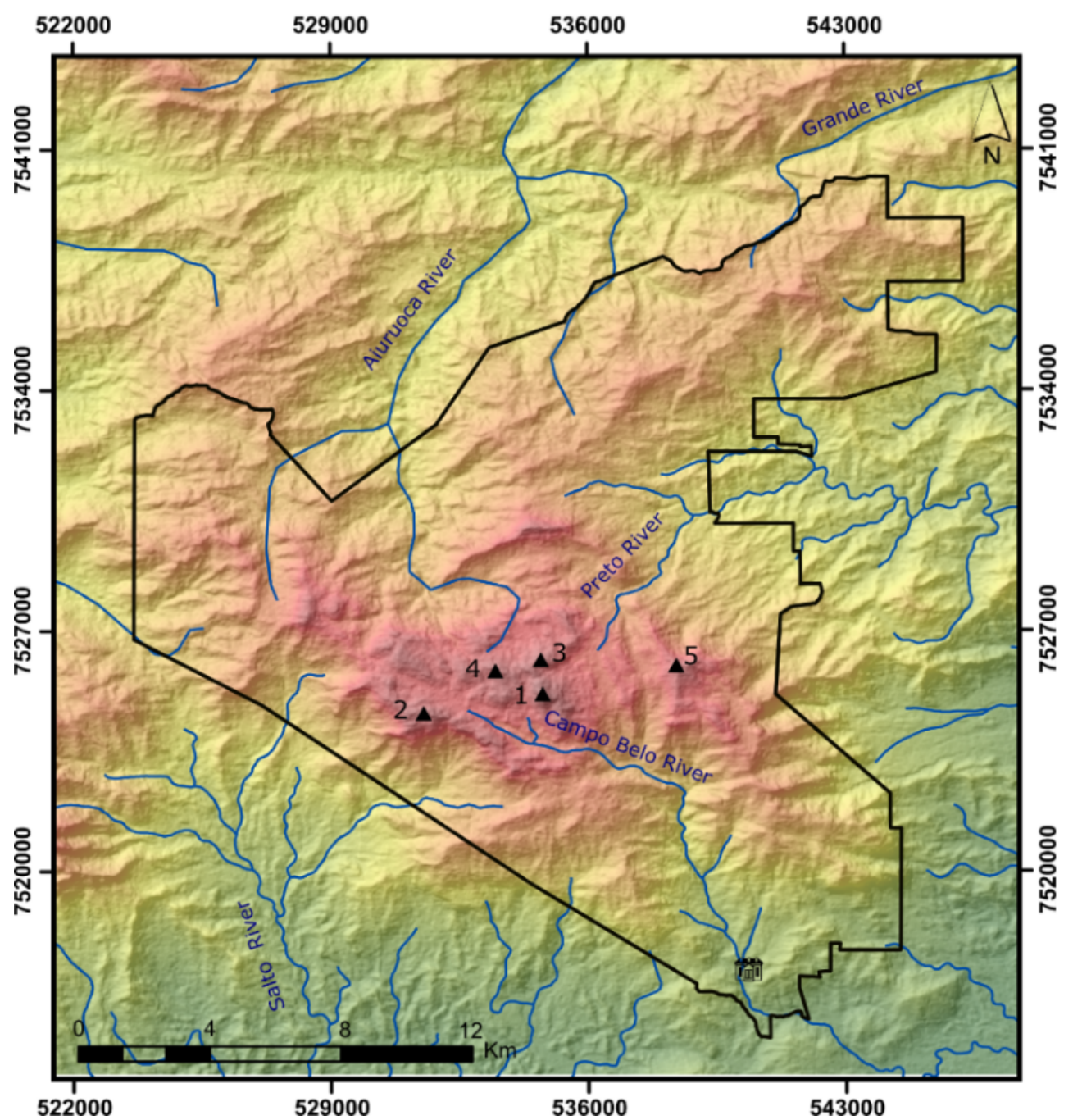

\section{Legend}

$\square$ Itatiaia National Park

Main hydrographical network

- Peak

init Head office

Elevation (m)

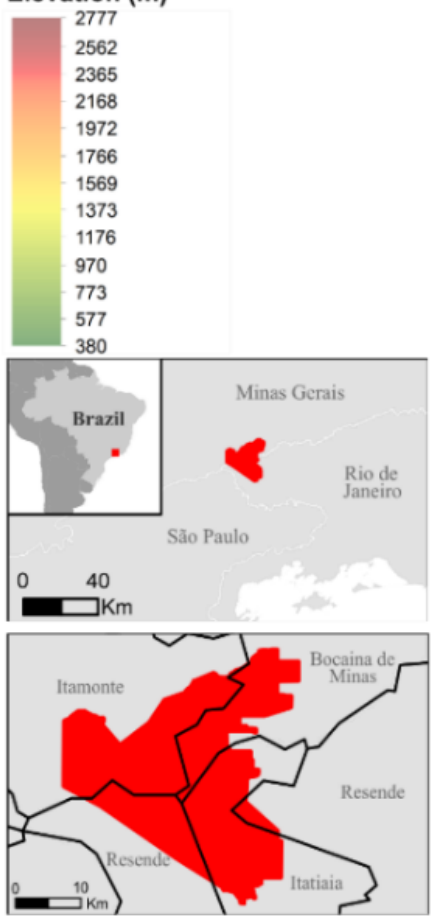

Geographic Information of the Itatiaia National Park. SRTM Elevation dataset.

Datum WGS 84.

UTM system: Zone $23 \mathrm{~S}$

Figure 1

Location map of the Itatiaia National Park with the main hydrographical network and the five highest peaks 1: Agulhas Negras Peak. 2: Pedra do Couto Hill. 3: Pedra do Sino Hill. 4: Pedra do Altar Hill. 5: Maromba Hill. 

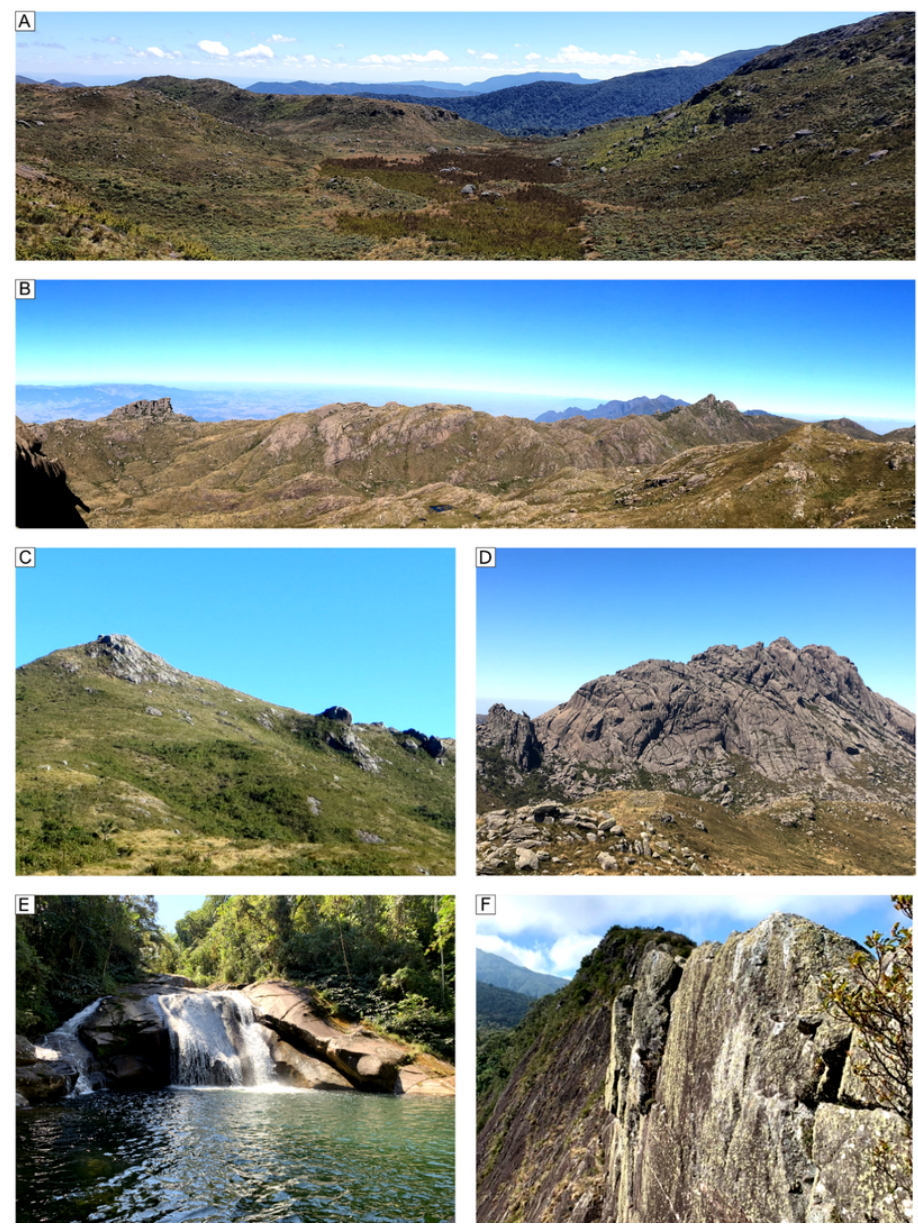

\section{Figure 2}

Representative geosites of the Itatiaia National Park according to the geological frameworks. (A) Bog of Aiuruoca River (1) (Quaternary deposits). (B) Fault Escarpment of Couto-Prateleiras Hills (6) (Cenozoic tectonism). (C) Breccia of Pedra Furada Hill (8) (Third magmatic stage of alkaline intrusion). (D) Fluted erosion of Agulhas Negras Hill (10) (Second magmatic stage of alkaline intrusion). (E) Waterfalls of Campo Belo River Basin (13) (Third magmatic stage of alkaline intrusion). (F) Metagranitoid of Enamorados Peak (16) (Proterozoic igneous and metamorphic rocks). (Figures A, B, C, D and E: photos by Vanessa C. Mucivuna and Figure F: photo by Jobson Pereira). 

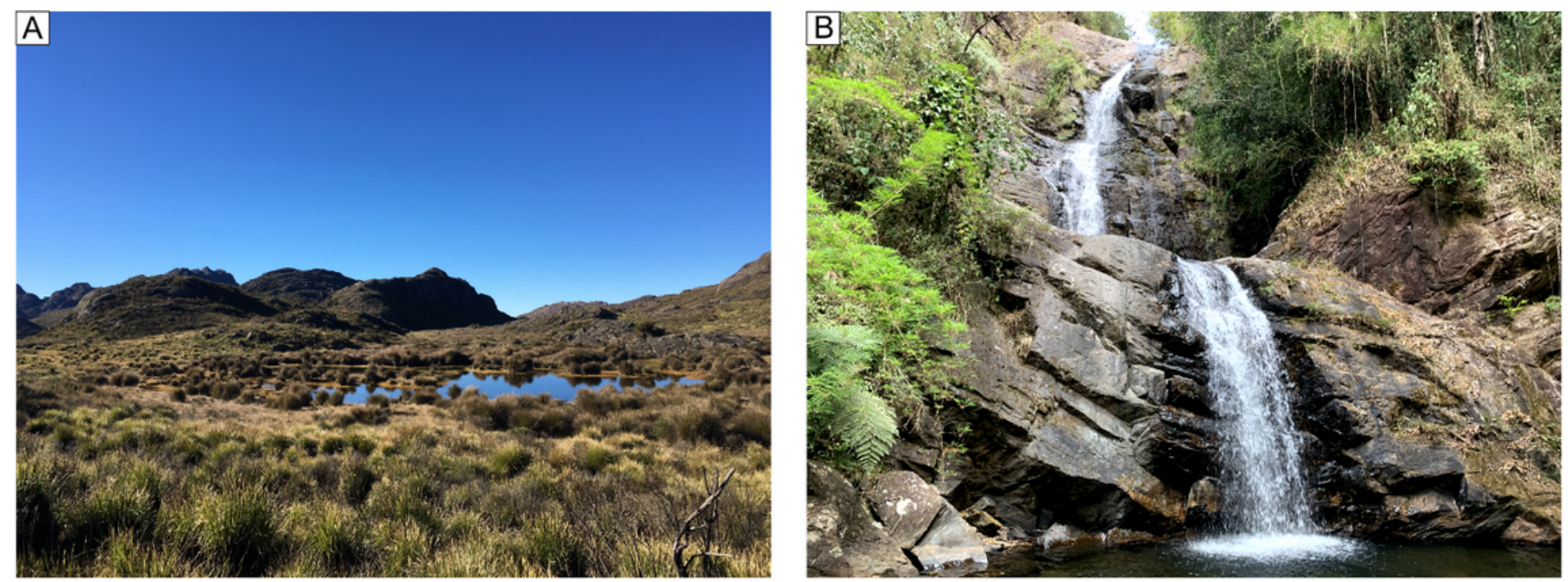

C

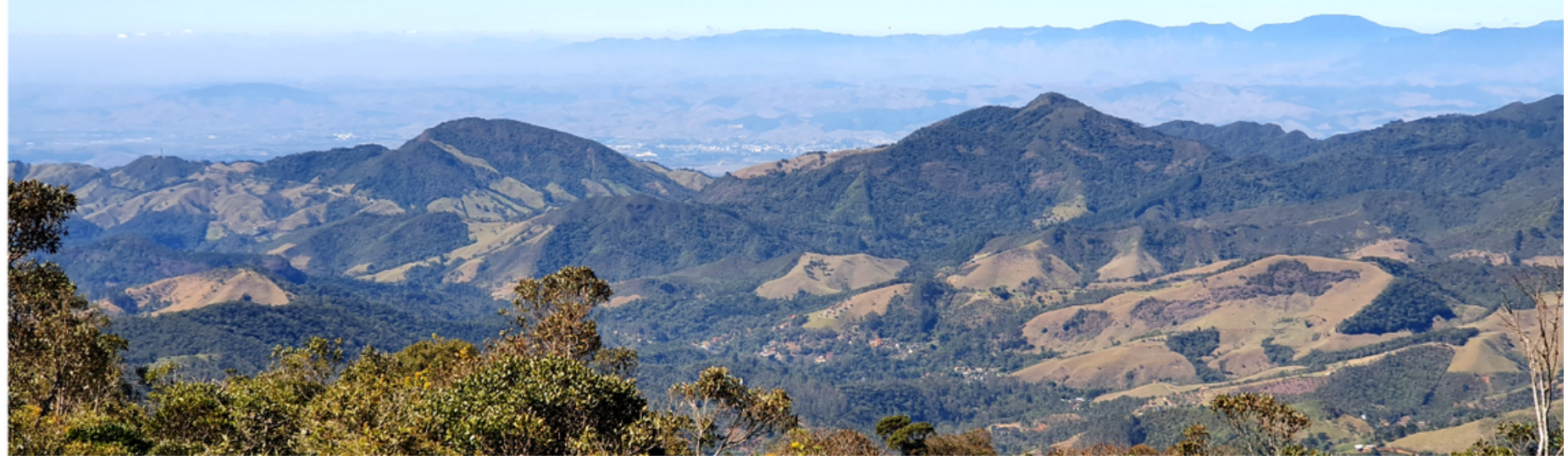

Figure 3

Representative sites with educational and recreative values of the Itatiaia National Park. (A) Geodiversity site Lakes and wetlands with peat deposits (18) (educational value). (B) Geodiversity site Gneiss of Cristais Waterfall (24) (recreative value). (C) Viewpoint Alto dos Brejos Hill (27) (educational and recreative values). (Figures A, B and C: photos by Vanessa C. Mucivuna).
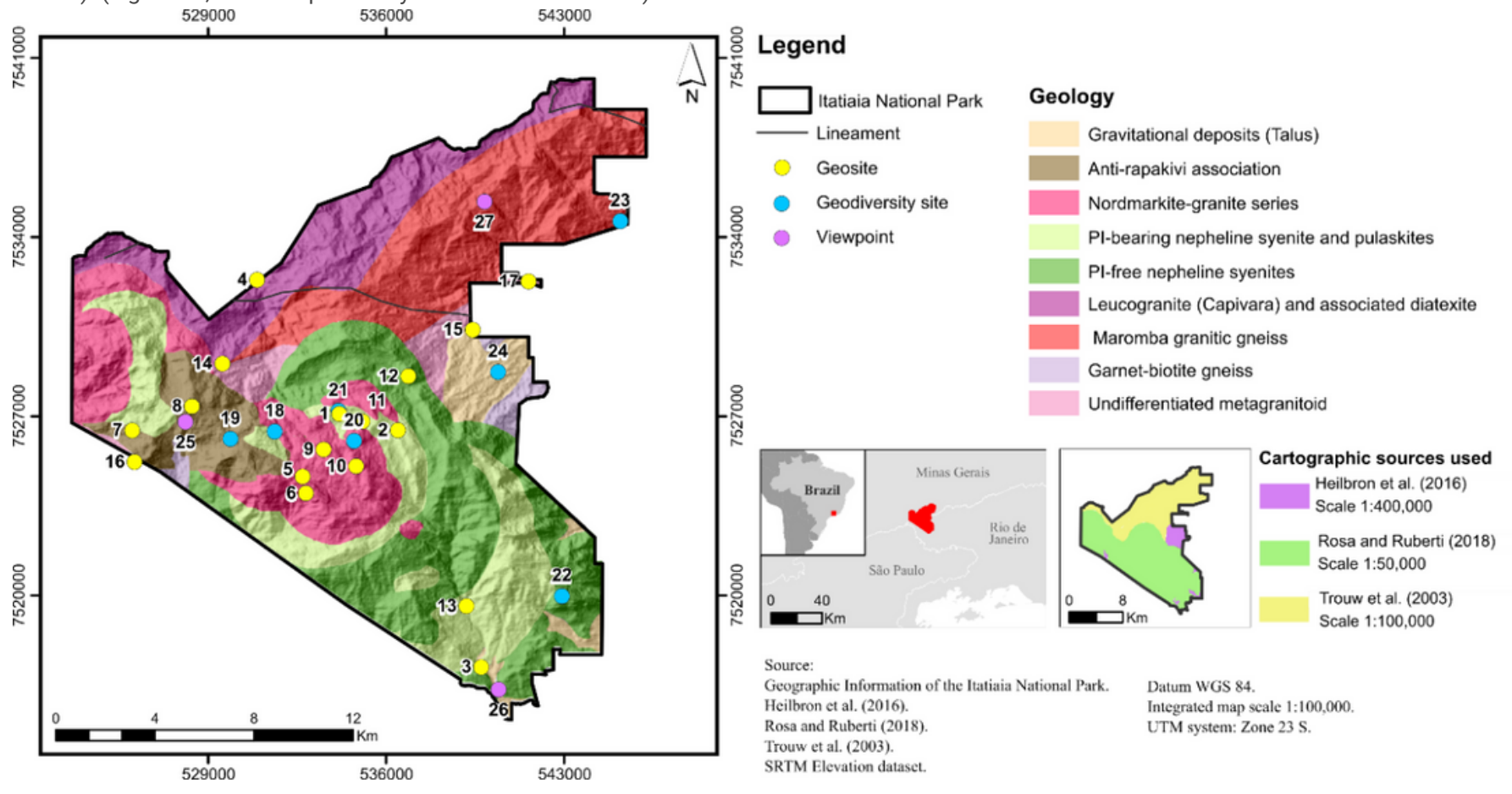
Figure 4

Inventoried sites in the Itatiaia National Park. (1) Bog of Aiuruoca River; (2) Bog of Preto River; (3) Fluvial deposits of Lago Azul; (4) Talus deposits of Serra Negra village; (5) Structural valley of Campo Belo River; (6) Fault Escarpment of Couto-Prateleiras Hills; (7) Biotite monzonite quarry; (8) Breccia of Pedra Furada Hill; (9) Fracture planes of Pedra do Altar Hill; (10) Fluted erosion of Agulhas Negras Hill; (11) Ovos da Galinha boulders and trachyte dyke swarm; (12) Ring-dyke on Itatiaia Plateau; (13) Waterfalls of Campo Belo River Basin; (14) Leucogranite of Pedra Grande Hill; (15) Tectonics records of Rio Preto Waterfalls; (16) Metagranitoid of Enamorados Peak; (17) Mylonitic gneiss of Santa Clara Waterfall; (18) Lakes and wetlands with peat deposits; (19) Breccia of Camelo Hill; (20) Pitted erosion of Pedra do Sino Hill; (21) Aiuruoca Waterfall; (22) Nepheline syenite of Três Picos Hill; (23) Granitic gneiss of Alcantilado Waterfall; (24) Gneiss of Cristais Waterfall; (25); Flores Highway (26) Último Adeus; and (27) Alto dos Brejos Hill. 